\title{
Growth and Adaptation of Estuarine Unicellular Algae in Media with Excess Copper, Cadmium or Zinc, and Effects of Metal-Contaminated Algal Food on Crassostrea virginica Larvae*
}

\author{
Gary H. Wikfors and Ravenna Ukeles
}

National Marine Fisheries Service, Northeast Fisheries Center, Milford Laboratory, Milford, Connecticut 06460-6499, USA

\begin{abstract}
Responses of the estuarine unicellular algae Monochrysis lutheri, Isochrysis galbana, Dunaliella euchlora, and Phaeodactylum tricornutum to excess $\mathrm{CuCl}_{2}, \mathrm{CdCl}_{2}$, and $\mathrm{ZnCl}_{2}$ in growth media were determined. Tolerance to metals in artificial seawater was much greater than in enriched natural seawater, presumably because of the higher concentration of metal ligands in the former. Growth differences between species in media containing excess $\mathrm{Cu}$ or $\mathrm{Cd}$ were observed in both media tested. Growth of $M$. lutheri and $I$. galbana was inhibited considerably more than that of the other test organisms. This difference did not occur in media with excess Zn. After extended periods of subculture in sublethal concentrations of $\mathrm{Cu}$ and $\mathrm{Cd}$, algae developed tolerances to metal concentrations that were inhibitory upon initial exposure. Strains of $I$.galbana adapted to grow in a medium with $10 \mathrm{mg} \% \mathrm{CuCl}_{2}$ $(47.3 \mathrm{ppm} \mathrm{Cu})$ or $2.5 \mathrm{mg} \% \mathrm{CdCl}_{2}(15.3 \mathrm{ppm} \mathrm{Cd})$ were fed to laboratory-reared veliger larvae of the oyster Crassostrea virginica. These algal foods induced poor growth and high mortalities in grazing larvae. We conclude that pollution of estuarine waters with high concentrations of metals can decrease primary productivity and alter algal species dominance. With continued exposure to sublethal concentrations, phytoplankters can exhibit a limited increase in tolerance and adaptation to the metals. These populations are then potentially toxic for grazing species at higher trophic levels.
\end{abstract}

\section{INTRODUCTION}

An increasing body of knowledge is revealing detrimental effects of waste materials on marine life (e.g. Bryan, 1971; Korringa, 1971; Friberg et al., 1974; Cole, 1979). In recent years, the ubiquitous use of metals throughout the world has resulted in the production of highly concentrated metallic wastes which are often released directly into the marine environment or eventually find their way into coastal waters from a variety of dump sites. Metal pollution is a worldwide problem. Abnormally high concentrations of metals have been reported from coastal waters of the southeastern United States (Windom and Smith, 1972), the Japanese coast (Ikuta, 1968), the coast of Spain (Establier and Pasqual, 1974), the British coast (Boyden, 1975), New

\footnotetext{
- This manuscript is a portion of a thesis submitted by Gary $\mathrm{H}$. Wikfors in partial fulfillment of the requirements for the degree of Master of Science at the University of Bridgeport
}

Zealand (Nielsen, 1975), Long Island Sound (Greig et al., 1977), the coast of Israel (Amiel and Navrot, 1978), and the St. Lawrence River estuary (Cossa and Poulet, 1978).

Bivalves concentrate some required metals to levels in excess of those found in metalloenzymes (Wolfe, 1970; Coombs, 1972, 1974), as well as other metals for which no requirement has been demonstrated (Pringle et al., 1968; Feng and Ruddy, 1974; Valiela et al., 1974). A data bibliography compiled by Kidder (1977) lists 189 published articles reporting concentrations of heavy metals found in bivalves collected throughout the world. Although the latter publication indicates that much research has been conducted to determine the concentration of heavy metals stored in adult bivalves, with the exception of the study of Calabrese et al. (1977) on larvae of the American oyster Crassostrea virginica and the hard clam Mercenaria mercenaria, little interest has been shown in determining the tolerance to metals of the more fragile larval stages. 
Some micro-algae have been shown to tolerate moderately high concentrations of heavy metals (Cossa, 1976; Braek et al., 1980). This tolerance suggests the possibility that metals may accumulate in phytoplankters and can be transferred from foods to grazing species; thus, metals can reach the higher trophic levels. Concern over this accumulation of metals by commercially marketed marine species has been voiced in the public press (e.g. The New York Times, 1978, 1980), as well as the scientific literature (e.g. Hall et al., 1976). In this latter study, cadmium concentrations up to $20 \mathrm{ppm}$ were found in some fish products intended for human consumption.

For purposes of ecological management it is important to gain an understanding of the routes by which high concentrations of metals are accumulated in fish and shellfish. The present study investigates (1) effects of the heavy metals copper, cadmium and zinc on growth rates of 4 estuarine unicellular algae in controlled culture media containing different concentrations of chelate; (2) the potential of the algae for adaptation to excess metal concentrations in growth media; (3) the effects of algal food cultured in high metal concentrations on grazing Crassostrea virginica larvae.

\section{MATERIALS AND METHODS}

Experiments were conducted with axenic cultures of the following algae: the flagellates Monochrysis
Iutheri Droop, Isochrysis galbana Parke, Dunaliella euchlora Lerche (the latter strain identified by Dr. R. A. Lewin but referred to as $D$. tertiolecta by McLachlin, 1960), and the diatom Phaeodactylum tricornutum Bohlin. These algal strains have been maintained in the Milford Laboratory Collection for many years as axenic cultures in media identical to those utilized in these experiments.

Algae were cultured in Pyrex screw-capped test tubes (19 $\mathrm{mm} \times 150 \mathrm{~mm}$, with liners in caps removed) and Erlenmeyer screw-capped flasks when larger volumes of culture were required. Glassware was washed in detergent (AlCo-Jet), rinsed with tap and distilled water, and immersed for at least $1 \mathrm{~h}$, twice in boiling glass-distilled water

Seawater from the Milford Long Island Sound estuary (salinity: $27-28 \mathrm{ppt}$ ) was stored in a 10,000-gallon (ca. 40,000 l) fiberglass-lined attic tank and brought into laboratories by gravity flow. Seawater was filtered through 10 and $1 \mu \mathrm{m}$ polypropylene filter cartridges (Filterite Corp., Maryland, USA), irradiated by twin 18inch ultraviolet lights (design description in Loosanoff and Davis, 1963), and finally passed through an activated charcoal filter cartridge (Barnstead). Two different media formulations were used: an enriched natural seawater medium, E (Ukeles, 1973) and an artificial seawater medium, $\mathrm{ASP}_{2}$ (Provasoli et al., 1957) (Table 1). Concentrations of tested metal salts are expressed in $\mathrm{mg} \%$, i.e. $\mathrm{mg}$ weight per $100 \mathrm{ml}$ solution, because this is the usual method of expres-

Table 1. Algal culture media (concentrations $\mathrm{l}^{-1}$ )

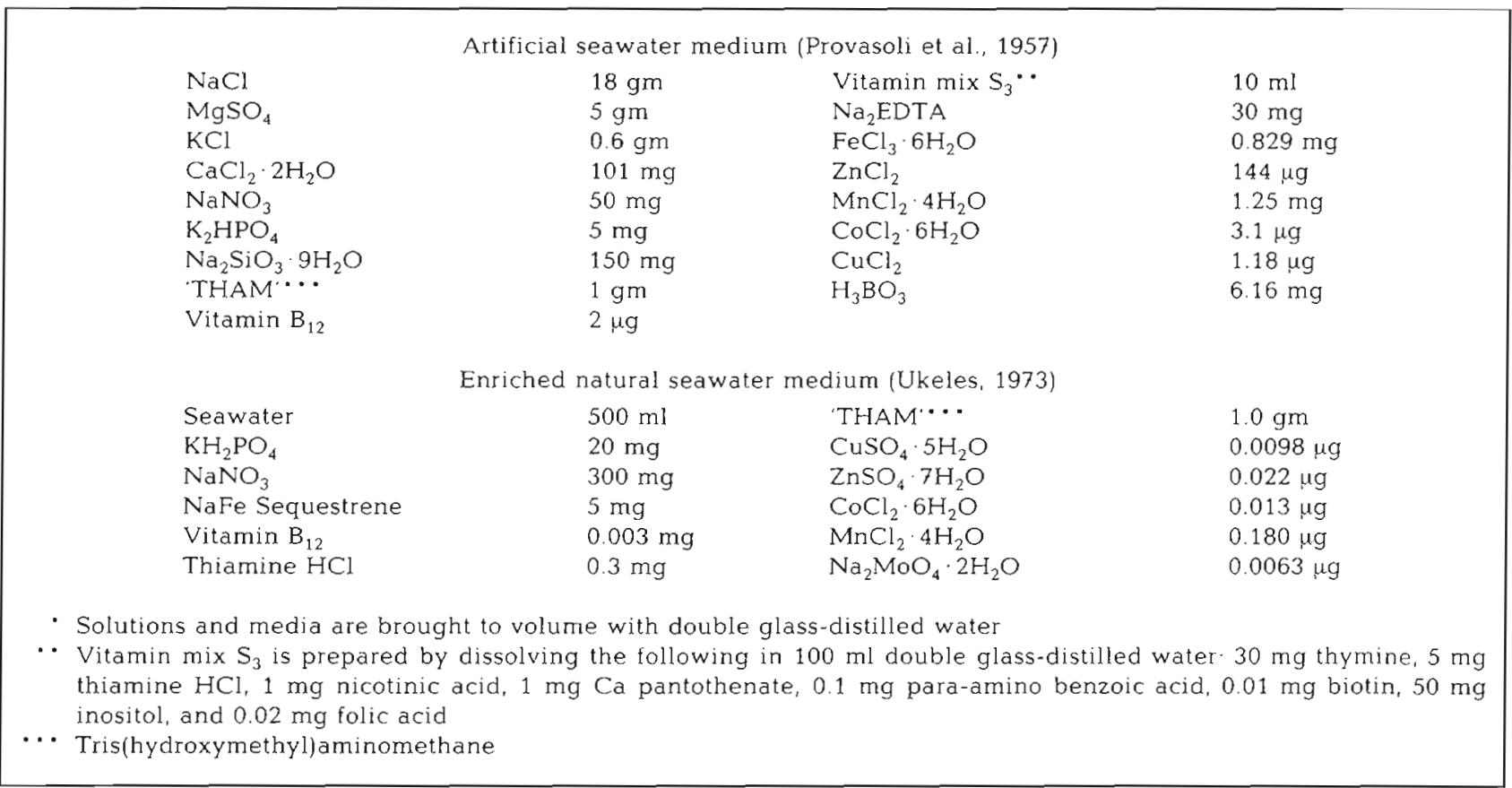


sing concentrations of nutrients in phycological studies. Retaining this convention facilitates comparisons between experimental metal salt concentrations and those concentrations used in normal growth media. Where appropriate, concentrations of metals are also expressed as mg metal ion per liter (ppm). the designation most often used for water quality criteria. It should be noted that these values do not represent ionic concentrations available to the algae as a large percentage of the metal ions are bound by chelating agents in the growth media. Copper, as well as zinc and cadmium, was tested as sulfate salt in the natural seawater medium since $\mathrm{CuSO}_{4}$ and $\mathrm{ZnSO}_{4}$ are routinely used as trace metal components. Metals were added as chloride salts in experiments with artificial seawater medium as chloride is the anion of the copper and zinc salts in this formulation.

The maximum concentrations of the metals that could be tested were limited to those which remained soluble in the alkaline growth media.

All algal culture media were steam-sterilized in a Castle autoclave for $20 \mathrm{~min}$ at $15-17 \mathrm{lb}$ atm pressure and allowed to equilibrate at least $24 \mathrm{~h}$ between sterilization and inoculation. Stock cultures of each organism were maintained in test tubes containing $10 \mathrm{ml}$ of $\mathrm{ASP}_{2}$ or E medium and subcultured routinely every $14 \mathrm{~d}$. Experimental cultures were inoculated aseptically with $0.5 \mathrm{ml}$ of a 14 -d stock culture, and each test was conducted in triplicate. Algal cultures were incubated in a Sherer Series RI-LTP Lighted Bioincubator equipped with cool-white fluorescent lights. Illumination was about $500 \mathrm{ft} \mathrm{C}$ on a $12 / 12 \mathrm{~h}$ light/dark cycle and temperature was maintained at $20^{\circ} \mathrm{C}\left( \pm 1 \mathrm{C}^{\circ}\right)$. Cell counts of culture samples were made in an Improved Neubauer Hemacytometer (Bright-Line). Culture density was determined in matched calibrated test tube cuvettes, using standard blanks of uninoculated medium for each metal concentration, in a Bausch and Lomb Spectronic $20 \mathrm{Col}-$ orimeter-spectrophotometer at $520 \mathrm{~nm}$. Experimental results of algal growth studies were expressed as the ratio of growth in excess metals to that of control cultures; this ratio was converted to a percent value.

Experiments were designed to determine levels of lethal, sublethal, and non-inhibitory concentrations of $\mathrm{Cu}, \mathrm{Zn}$, and $\mathrm{Cd}$ in natural and artificial seawater media. Species were cultured in sublethal concentrations of copper and cadmium at different initial cell concentrations to determine if cell density influenced metal tolerance. Capacities of algal species to adapt to metals were investigated by subculture every $2 \mathrm{w}$ in $\mathrm{ASP}_{2}$ medium containing sublethal metal concentrations. Culture densities were determined spectrophotometrically. At subculture 11, living cells from control cultures and from the highest concentration of each metal tolerated were examined microscopically for gross morphological changes.

Adult oysters Crassostrea virginica were induced to spawn in the laboratory by warm water stimulation (Loosanoff and Davis, 1963). Fertilized eggs were collected and washed on Nitex (monofilament nylon) screening and suspended at a concentration of $15 \mathrm{ml}^{-1}$ in $26^{\circ} \mathrm{C}$ seawater for $48 \mathrm{~h}$. Fully developed veliger larvae were washed on a 36 -mesh Nitex screen, resuspended, and counted in a Sedgwick-Rafter cell. Larvae were suspended to yield a concentration of 20 larvae $\mathrm{ml}^{-1}$ in $600 \mathrm{ml}$ of seawater in polypropylene beakers that were incubated on a water table maintained at $26{ }^{\circ} \mathrm{C}$.

Isochrysis galbana was studied in the larval feeding experiments because it is rapidly utilized and known to have high nutritional value for larvae (Davis and Guillard, 1958; Walne, 1963; Ukeles, 1971). In preparation for feeding of larvae, algae were concentrated by centrifugation at 1500 RPM $(276 \mathrm{G})$ in an IEC International Centrifuge (Model $\mathrm{PR}_{2}$ ) for $8 \mathrm{~min}$ at $5{ }^{\circ} \mathrm{C}$. The supernatant medium was decanted, and the cells were resuspended in $40 \mathrm{ml}$ of filter-sterilized seawater. This washed cell suspension was added to the larval culture as food source. I. galbana were fed at a concentration of $16.5 \times 10^{3}$ cells $\mathrm{ml}^{-1}$ of larval culture. Investigations of larval growth were conducted on the following feeding regimes: (1) unfed larvae; (2) unfed larvae, with solutions of $\mathrm{CuCl}_{2}$ or $\mathrm{CdCl}_{2}$ added to the culture; (3) larvae fed algae cultured in $\mathrm{ASP}_{2}$ growth medium and, also, solutions of $\mathrm{CuCl}_{2}$ or $\mathrm{CdCl}_{2}$ added to the larvae; (4) larvae fed algae adapted to grow in $\mathrm{ASP}_{2}$ growth medium containing high concentrations of $\mathrm{CuCl}_{2}$ or $\mathrm{CdCl}_{2}$.

At 24 -h intervals, starting $48 \mathrm{~h}$ after fertilization, larvae from each beaker were collected on a 36-mesh Nitex screen, washed with a pressurized stream of seawater, and resuspended in beakers containing $500 \mathrm{ml}$ of seawater A $20-\mathrm{ml}$ sample was taken from each beaker and preserved in $4 \%$ formalin. Additions of food and metals were again made, the volume brought to $500 \mathrm{ml}$ with seawater, and the beakers reincubated.

Daily microscopic examinations were conducted to observe the qualitative appearance of the living larvae, and 1-ml fixed samples were counted in a Sedgwick-Rafter chamber to determine dead/live ratios. For growth determinations, 50 larvae were measured along the widest dimension of their shell parallel to the straight-hinge, using a Bausch and Lomb Balplan microscope with a calibrated eyepiece scale.

Samples of larvae from each feeding regime were taken $1 \mathrm{~h}$ after the 9 th feeding for observation of feeding behavior by epifluorescence microscopy, as described by Babinchak and Ukeles (1979). Larvae 
were examined for fluorescence of algae within the gut with a Bausch and Lomb Balplan fluorescence microscope (using the incidence fluorescence mode) fitted with an ABO-50 W mercury vapor lamphouse power supply. A Bausch and Lomb 35-mm camera with a Bausch and Lomb AX-1 Automatic Exposure Controller was used for photographing samples on Kodak Tri$\mathrm{X}$ pan film.

\section{RESULTS}

\section{Responses of Algae to Metals in Artificial Seawater}

Above a threshold value, there was a direct relationship of metal concentration to growth inhibition. The response to metals varied between species. Monochrysis lutheri and Isochrysis galbana demonstrated very similar responses and were considerably more sensitive to the metals than were Dunaliella euchlora or Phaeodactylum tricornutum.

No significant growth inhibition in the artificial seawater medium was observed in $\mathrm{CuCl}_{2}$ concentrations below $5 \times 10^{-1} \mathrm{mg} \%$ (2.37 ppm Cu). Partial inhibition of Isochrysis galbana occurred in $5 \mathrm{mg} \% \mathrm{CuCl}_{2}$, reducing growth in the metal to $73.6 \%$ of the control. The other species were less affected at this concentration: $81.4 \%$ for Monochrysis lutheri, $89.5 \%$ for Phaeodacty- lum tricornutum, and $93.7 \%$ for Dunaliella euchlora. These relations in growth rate were repeated at $10 \mathrm{mg} \%$ and $25 \mathrm{mg} \% \mathrm{CuCl}_{2}$. At the latter concentration, growth of $M$. lutheri and I. galbana was only $11.2 \%$ and $14.3 \%$, respectively, of that in the controls However, P. tricornutum populations increased to $59.2 \%$ of the control and $D$. euchlora was only slightly inhibited (Table 2).

$\mathrm{ZnCl}_{2}$, at or less than $1 \mathrm{mg} \%$ (4.80 ppm $\left.\mathrm{Zn}\right)$, caused no significant inhibition of any of the algae tested. In medium with $3 \mathrm{mg} \% \mathrm{ZnCl}_{2}$, all species were similarly reduced in growth to between $74-79 \%$ of the control. In media with $5 \mathrm{mg} \%$ and $7 \mathrm{mg} \%$, somewhat more inhibition was observed (Table 2).

The most pronounced differences in response between species to a metal salt were observed in experiments testing effects of $\mathrm{CdCl}_{2}$. Although no significant growth inhibition occurred in less than $2.5 \mathrm{mg} \% \mathrm{CdCl}_{2}(15.3 \mathrm{ppm} \mathrm{Cd})$, at this concentration growth of Monochrysis lutheri and Isochrysis galbana was almost completely inhibited. In $5 \mathrm{mg} \% \mathrm{CdCl}_{2}$, growth of $M$. lutheri and I. galbana ceased; whereas, Dunaliella euchlora and Phaeodactylum tricornutum achieved densities of $64.3 \%$ and $80.1 \%$, respectively, of the controls. At $20 \mathrm{mg} \% \mathrm{CdCl}_{2}$, growth of $D$. euchlora was severely reduced, but $50 \mathrm{mg} \%$ was required to cause this drastic reduction in $P$. tricornutum (Table 2).

Table 2. Growth of algal populations exposed to metals in artificial seawater medium (ASP $)_{2}$, observed after $12 \mathrm{~d}_{i}$ growth expressed as percentage of that obtained in absence of metal. Dash: no experiment

\begin{tabular}{|c|c|c|c|c|c|c|c|}
\hline & \multicolumn{3}{|c|}{ Concentration } & \multicolumn{4}{|c|}{ Algal species } \\
\hline & $\begin{array}{l}\text { Metal salt } \\
(\mathrm{mg} \%)\end{array}$ & & $\begin{array}{l}\text { Metal ion } \\
\quad(\mathrm{ppm})\end{array}$ & $\begin{array}{c}\text { Monochrysis } \\
\text { lutheri }\end{array}$ & $\begin{array}{l}\text { Isochrysis } \\
\text { galbana }\end{array}$ & $\begin{array}{c}\text { Dunaliella } \\
\text { euchlora }\end{array}$ & $\begin{array}{l}\text { Phaeodactylum } \\
\text { tricornutum }\end{array}$ \\
\hline \multirow[t]{7}{*}{$\mathrm{CuCl}_{2}$} & 0.005 & $\mathrm{Cu}$ & 0.0237 & 119.3 & 99.0 & 103.7 & 104.9 \\
\hline & 0.01 & & 0.0473 & 100.2 & 99.0 & 99.4 & 103.7 \\
\hline & 0.1 & & 0.473 & 94.0 & 97.5 & 97.1 & 100.4 \\
\hline & 0.5 & & 2.37 & 92.8 & 101.9 & 94.1 & 98.4 \\
\hline & 5.0 & & 23.7 & 81.4 & 73.6 & 93.7 & 89.5 \\
\hline & 10.0 & & 47.3 & 71.9 & 66.1 & 96.4 & 74.8 \\
\hline & 25.0 & & 118 & 11.2 & 14.3 & 92.0 & 59.2 \\
\hline \multirow[t]{6}{*}{$\mathrm{ZnCl}_{2}$} & 0.025 & $\mathrm{Zn}$ & 0.120 & 99.0 & 98.9 & 98.0 & 98.1 \\
\hline & 0.1 & & 0.480 & 97.2 & 98.8 & 90.9 & 99.2 \\
\hline & 1.0 & & 4.80 & 94.5 & 93.4 & 89.9 & 98.8 \\
\hline & 3.0 & & 14.4 & 76.6 & 76.3 & 78.7 & 74.2 \\
\hline & 5.0 & & 24.0 & 71.7 & 75.6 & 68.6 & 62.7 \\
\hline & 7.0 & & 33.6 & 64.7 & 50.9 & 60.4 & 59.6 \\
\hline \multirow[t]{9}{*}{$\mathrm{CdCl}_{2}$} & 0.01 & $\mathrm{Cd}$ & 0.0613 & 97.2 & 92.8 & 95.6 & 100.9 \\
\hline & 0.1 & & 0.613 & 95.6 & 95.5 & 92.5 & 103.9 \\
\hline & 1.0 & & 6.13 & 92.8 & 92.8 & 97.2 & 103.0 \\
\hline & 2.5 & & 15.3 & 13.6 & 20.3 & - & - \\
\hline & 5.0 & & 30.7 & 6.2 & 8.3 & 64.3 & 80.1 \\
\hline & 10.0 & & 61.3 & 4.9 & 5.6 & 27.3 & 76.2 \\
\hline & 20.0 & & 123 & 4.9 & 4.7 & 5.6 & 52.3 \\
\hline & 25.0 & & 153 & - & - & 5.6 & 37.9 \\
\hline & 50.0 & & 306 & - & - & 5.0 & 9.2 \\
\hline
\end{tabular}


Table 3. Growth of algal populations exposed to metals in enriched natural seawater medium (E), observed after $12 \mathrm{~d}$; growth expressed as percentage of that obtained in absence of metal

\begin{tabular}{|c|c|c|c|c|c|c|c|}
\hline & \multicolumn{3}{|c|}{ Concentration } & \multicolumn{4}{|c|}{ Algal species } \\
\hline & $\begin{array}{l}\text { Metal salt } \\
(\mathrm{mg} \%)\end{array}$ & & $\begin{array}{l}\text { Metal ion } \\
\text { (ppm) }\end{array}$ & $\begin{array}{c}\text { Monochrysis } \\
\text { lutheri }\end{array}$ & $\begin{array}{l}\text { Isochrysis } \\
\text { galbana }\end{array}$ & $\begin{array}{l}\text { Dunaliella } \\
\text { euchlora }\end{array}$ & $\begin{array}{c}\text { Phaeodactylum } \\
\text { tricornutum }\end{array}$ \\
\hline \multirow[t]{3}{*}{$\mathrm{CuSO}_{4}$} & 0.119 & $\mathrm{Cu}$ & 0.473 & 98.3 & 94.9 & 88.6 & 94.6 \\
\hline & 1.19 & & 4.73 & 91.7 & 92.8 & 86.4 & 92.8 \\
\hline & 11.9 & & 47.3 & 10.3 & 7.4 & 81.2 & 85.8 \\
\hline \multirow[t]{3}{*}{$\mathrm{ZnSO}_{4}$} & 0.118 & $\mathrm{Zn}$ & 0.480 & 93.8 & 90.8 & 88.7 & 91.0 \\
\hline & 1.18 & & 4.80 & 90.7 & 91.8 & 92.1 & 106.7 \\
\hline & 11.8 & & 48.0 & 36.5 & 36.8 & 38.4 & 25.8 \\
\hline \multirow{4}{*}{$\mathrm{CdSO}_{4}$} & 0.0114 & $\mathrm{Cd}$ & 0.0613 & 108.6 & 90.6 & 96.0 & 96.3 \\
\hline & 0.114 & & 0.613 & 107.3 & 90.7 & 99.4 & 101.9 \\
\hline & 1.14 & & 6.13 & 10.9 & 7.7 & 55.2 & 94.5 \\
\hline & 11.4 & & 61.3 & 10.0 & 7.7 & 7.3 & 43.1 \\
\hline
\end{tabular}

\section{Responses of Algae to Metals in Enriched Natural Seawater}

Differences in species tolerances to metal salts were similar to those observed in the artificial seawater medium although it soon became apparent that algae were less tolerant of cadmium and copper in the enriched natural seawater than in the artificial seawater medium. In contrast, tolerances of zinc were similar in both media.

Inhibition did not occur at or less than $1.19 \mathrm{mg} \%$ $\mathrm{CuSO}_{4}(4.73 \mathrm{ppm} \mathrm{Cu})$, but at $11.9 \mathrm{mg} \%$ population increases of Monochrysis lutheri and Isochrysis gal-

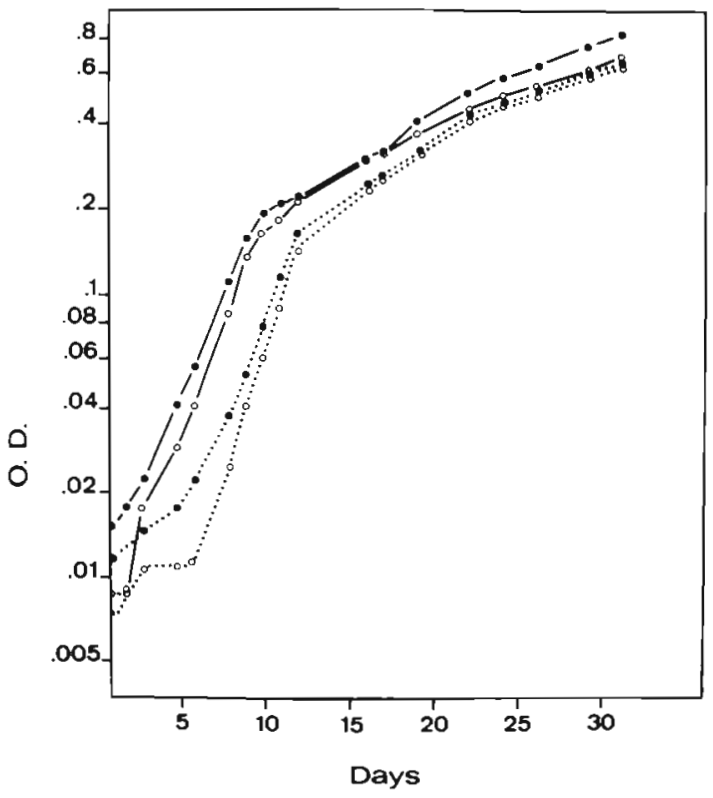

Fig. 1. Isochrysis galbana. Growth in $\mathrm{ASP}_{2}$ medium (solid lines) and in $\mathrm{ASP}_{2}$ with the addition of $0.1 \mathrm{mg} \% \quad \mathrm{CdCl}_{2}$ $(0.613 \mathrm{ppm} \mathrm{Cd})$ (dotted lines) at 2 initial cell populations, $9.2 \times 10^{4}$ cells $\mathrm{ml}^{-1}$ (solid circles) and $3.5 \times 10^{4}$ cells $\mathrm{ml}^{-1}$ (open circles) bana were almost completely inhibited. In contrast, at this latter concentration, Dunaliella euchlora and Phaeodactylum tricornutum displayed growth $81.2 \%$ and $85.8 \%$ of that in the controls (Table 3 ).

Growth was not inhibited in $0.118 \mathrm{mg} \%$ and $1.18 \mathrm{mg} \% \mathrm{ZnSO}_{4}$; in $11.8 \mathrm{mg} \% \mathrm{ZnSO}_{4}(48.0 \mathrm{ppm} \mathrm{Zn})$ very similar growth responses between $25.8 \%$ and $38.4 \%$ of the controls were observed in all species (Table 3).

None of the tested species were inhibited in $0.114 \mathrm{mg} \% \mathrm{CdSO}_{4}$, but in $1.14 \mathrm{mg} \% \mathrm{CdSO}_{4}$ (6.13 ppm Cd) growth of Monochrysis lutheri and Isochrysis galbana virtually ceased. In contrast, Dunaliella euchlora

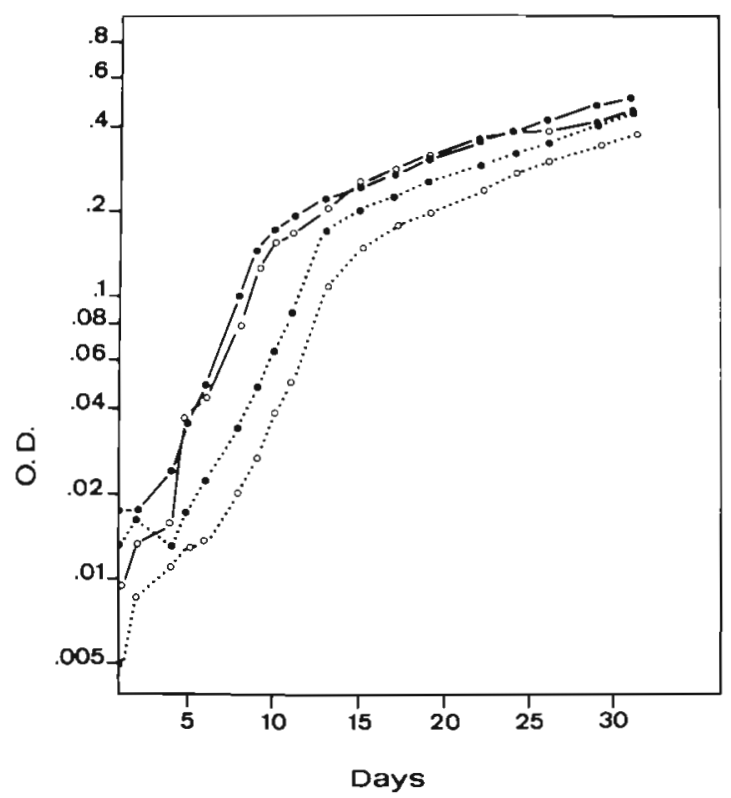

Fig. 2, Monochrysis lutheri. Growth in $\mathrm{ASP}_{2}$ medium (solid lines) and in $\mathrm{ASP}_{2}$ with the addition of $0.1 \mathrm{mg} \% \quad \mathrm{CdCl}_{2}$ $(0.613 \mathrm{ppm} \mathrm{Cd})$ (dotted lines) at 2 initial cell populations, $5.7 \times 10^{4}$ cells ml $\mathrm{ml}^{-1}$ (solid circles) and $1.5 \times 10^{4} \mathrm{cells} \mathrm{ml}^{-1}$ (open circles) 


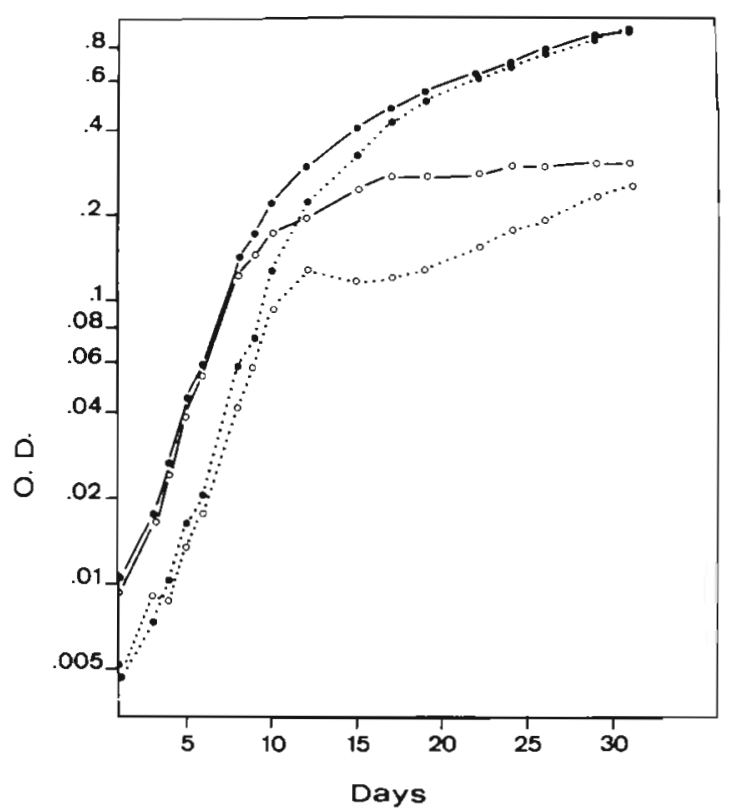

Fig. 3. Dunaliella euchlora. Growth in $\mathrm{ASP}_{2}$ medium (solid lines) and in $\mathrm{ASP}_{2}$ with the addition of $1.0 \mathrm{mg} \% \mathrm{CdCl}_{2}$ (6.13 ppm Cd) (dotted lines) at 2 initial cell populations, $4.1 \times 10^{4}$ cells ml $l^{-1}$ (solid circles) and $4.9 \times 10^{3}$ cells ml $l^{-1}$ (open circles)

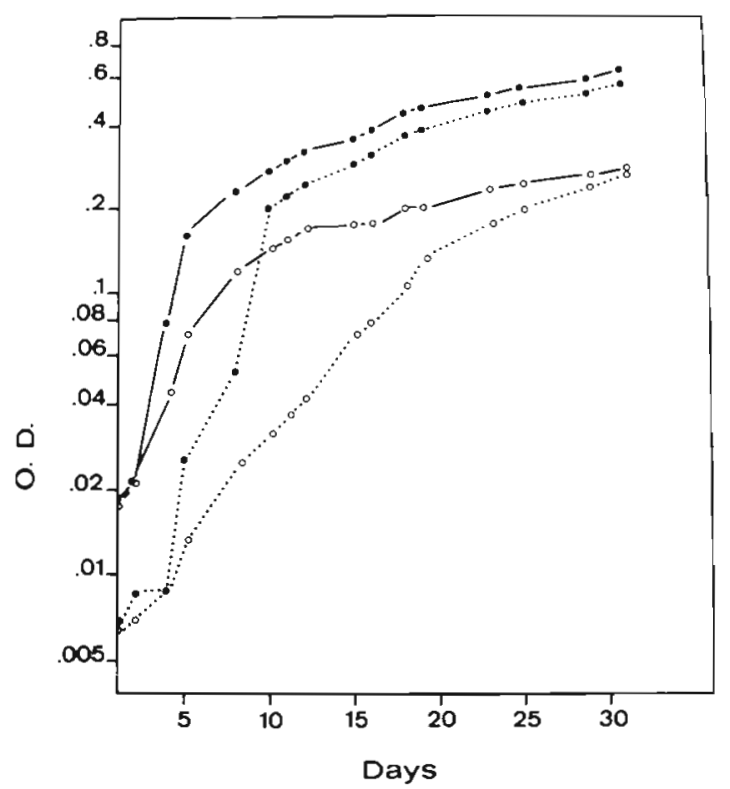

Fig. 4. Phaeodactylum tricornutum. Growth in $\mathrm{ASP}_{2}$ medium (solid lines) and in $\mathrm{ASP}_{2}$ with the addition of $10 \mathrm{mg} \% \mathrm{CdCl}_{2}$ $(61.3 \mathrm{ppm} \mathrm{Cd})$ (dotted lines) at 2 initial cell populations, $2.4 \times 10^{5}$ cells ml-1 (solid circles) and $2.0 \times 10^{4}$ cells ml ${ }^{-1}$ (open circles)

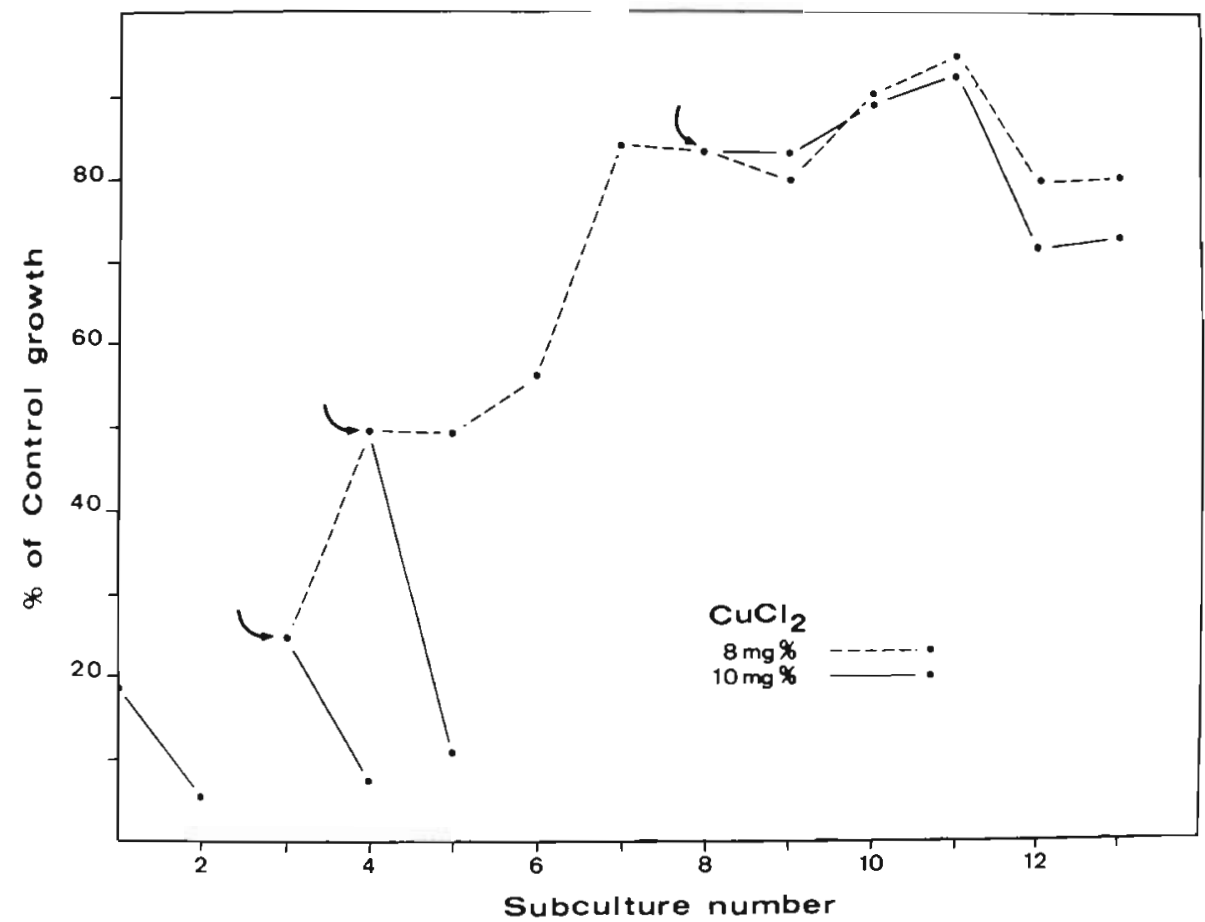

Fig. 5. Monochrysis lutheri. Growth during extended exposure to copper by periodic subculture in $\mathrm{ASP}_{2}$ medium containing added $\mathrm{CuCl}_{2} \quad(8 \mathrm{mg} \%$ $\mathrm{CuCl}_{2}=37.8 \mathrm{ppm} \mathrm{Cu} ; \quad 10 \mathrm{mg} \%$ $\mathrm{CuCl}_{2}=47.3 \mathrm{ppm}$ (u). Arrows: subcultures at which cells growing in one concentration of the metal were continued in this medium and also transferred into an additional higher or lower concentration of $\mathrm{CuCl}_{2}$. At the $3 \mathrm{rd}$ subculture the stock strain growing in $\mathrm{ASP}_{2}$ was transferred into $8 \mathrm{mg} \% \mathrm{CuCl}_{2}$ and Phaeodactylum tricornutum were fairly tolerant; their populations increased to $55.2 \%$ and $94.5 \%$, respectively, of the controls. Similarly, in $11.4 \mathrm{mg} \%$ $\mathrm{CdSO}_{4} P$. tricornutum was more resistant than $D$. euchlora (Table 3)

Algal density affected the response to sublethal cad- mium concentrations in different ways. In media with cadmium, Monochrysis lutheri and Isochrysis galbana at lower initial cell densities had a longer lag period than the controls or cultures in cadmium with higher initial cell density. The 2 initial $I$. galbana densities attained the same maximal populations, but $M$. Iutheri 
Fig. 6. Monochrysis lutheri. Growth during extended exposure to zinc by periodic subculture in medium containing added $\quad \mathrm{ZnCl}_{2} \quad(3.5 \mathrm{mg} \%$ $\mathrm{ZnCl}_{2}=16.8 \mathrm{ppm} \quad \mathrm{Zn}_{i} \quad 5 \mathrm{mg} \%$ $\mathrm{ZnCl}_{2}=24.0 \mathrm{ppm} \mathrm{Zn}$ ). Arrows: subcultures at which cells growing in one concentration of the metal were continued in this medium and also transferred into an additional higher or lower concentration of $\mathrm{ZnCl}_{2}$

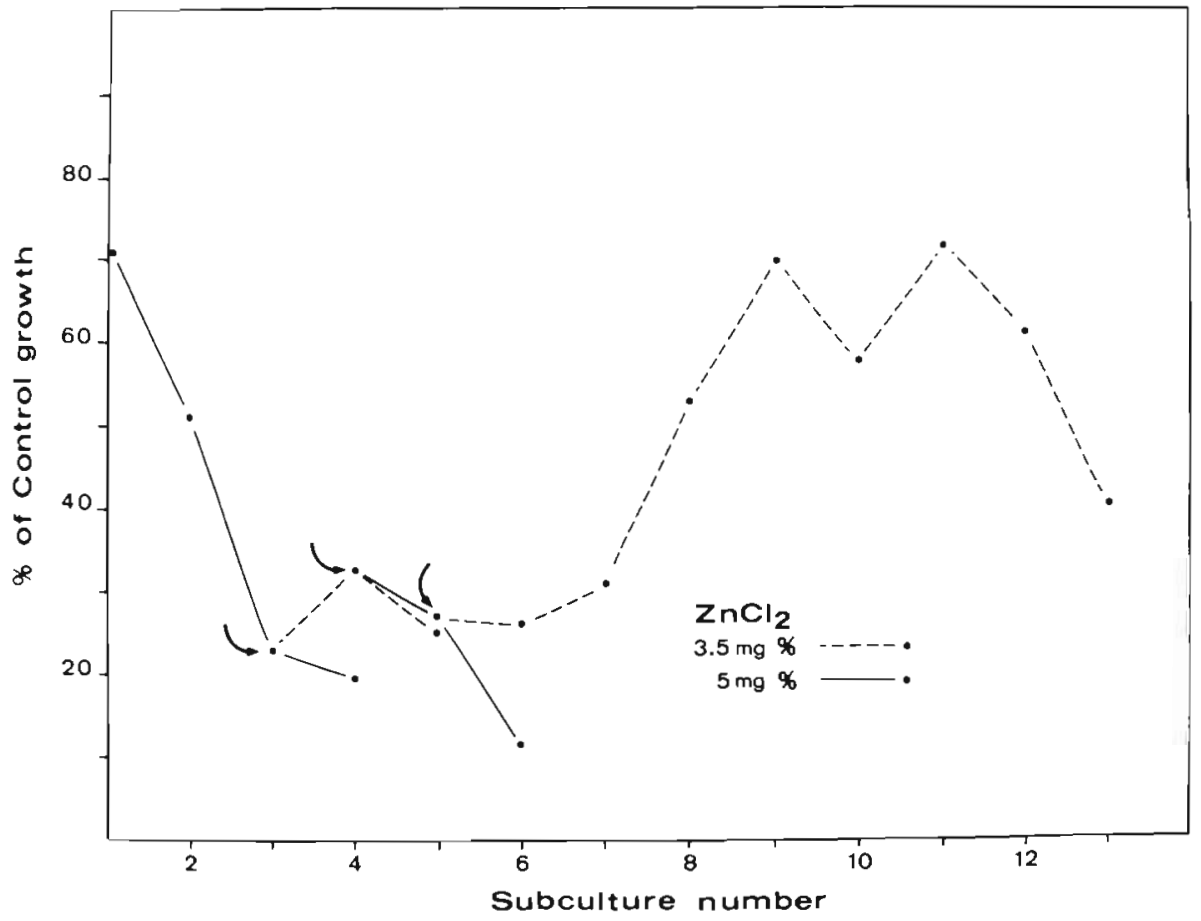

from the lower initial population density lagged behind in maximal cell numbers (Figs. 1, 2). These results seem to be related to the quantitative variations of the populations at the start of the experiment. With $I$. galbana, one population was higher than the other by a factor of 2.6 ; with $M$. lutheri, by a factor of 3.8. A still greater difference, i.e. by a factor of 8.5 in the initial populations of Dunaliella euchlora, decreased the growth rate of this species towards the end of the log phase of the growth curve (Fig. 3). The greatest effect of metal concentration upon culture response from 2 different initial populations was observed in the logarithmic phase of Phaeodactylum tricornutum (Fig. 4); in this species initial culture densities differed by a factor of 12 .

\section{Adaptation to Metals in Artificial Seawater}

Upon prolonged exposure, the algae demonstrated varying capacities to adapt to inhibitory metal concentrations. Monochrysis lutheri in artificial seawater with $10 \mathrm{mg}^{2} \quad \mathrm{CuCl}_{2} \quad(47.3 \mathrm{ppm} \mathrm{Cu})$ was severely reduced to $5.6 \%$ of the control values, but in $8 \mathrm{mg} \%$, growth was more successful and population density increased from $25 \%$ to over $90 \%$ of the control during 9 subcultures. This strain in the 8 th subculture was then inoculated into medium with $10 \mathrm{mg} \% \mathrm{CuCl}_{2}$. This time the strain yielded growth that was between $72 \%$ and $94 \%$ of the control population (Fig. 5).

Monochrysis lutheri in medium containing $5 \mathrm{mg} \%$

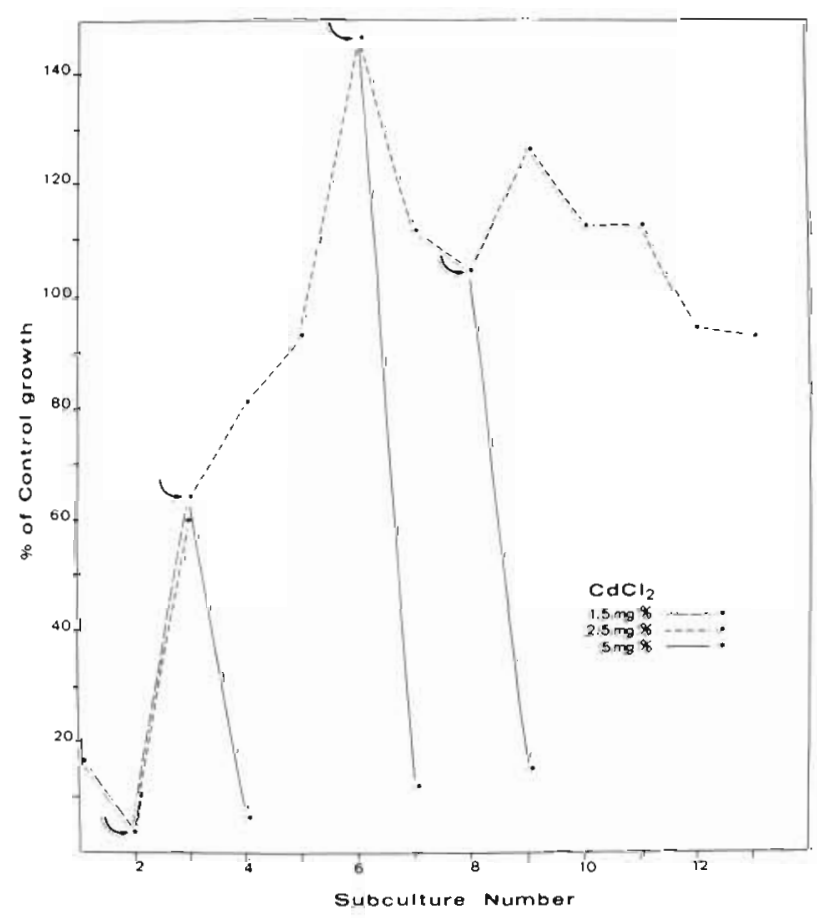

Fig. 7. Monochrysis lutheri. Growth during extended exposure to cadmium by periodic subculture in medium containing added $\mathrm{CdCl}_{2}\left(1.5 \mathrm{mg} \% \mathrm{CdCl}_{2}=9.20 \mathrm{ppm} \mathrm{Cd} ; 2.5 \mathrm{mg} \%\right.$ $\mathrm{CdCl}_{2}=15.3 \mathrm{ppm} \mathrm{Cd}$ i $5.0 \mathrm{mg} \% \quad \mathrm{CdCl}_{2}=30.7 \mathrm{ppm} \mathrm{Cd}$ ). Arrows: subcultures at which cells growing in one concentration of the metal were continued in this medium and also transferred into an additional higher or lower concentration of $\mathrm{CdCl}_{2}$ 


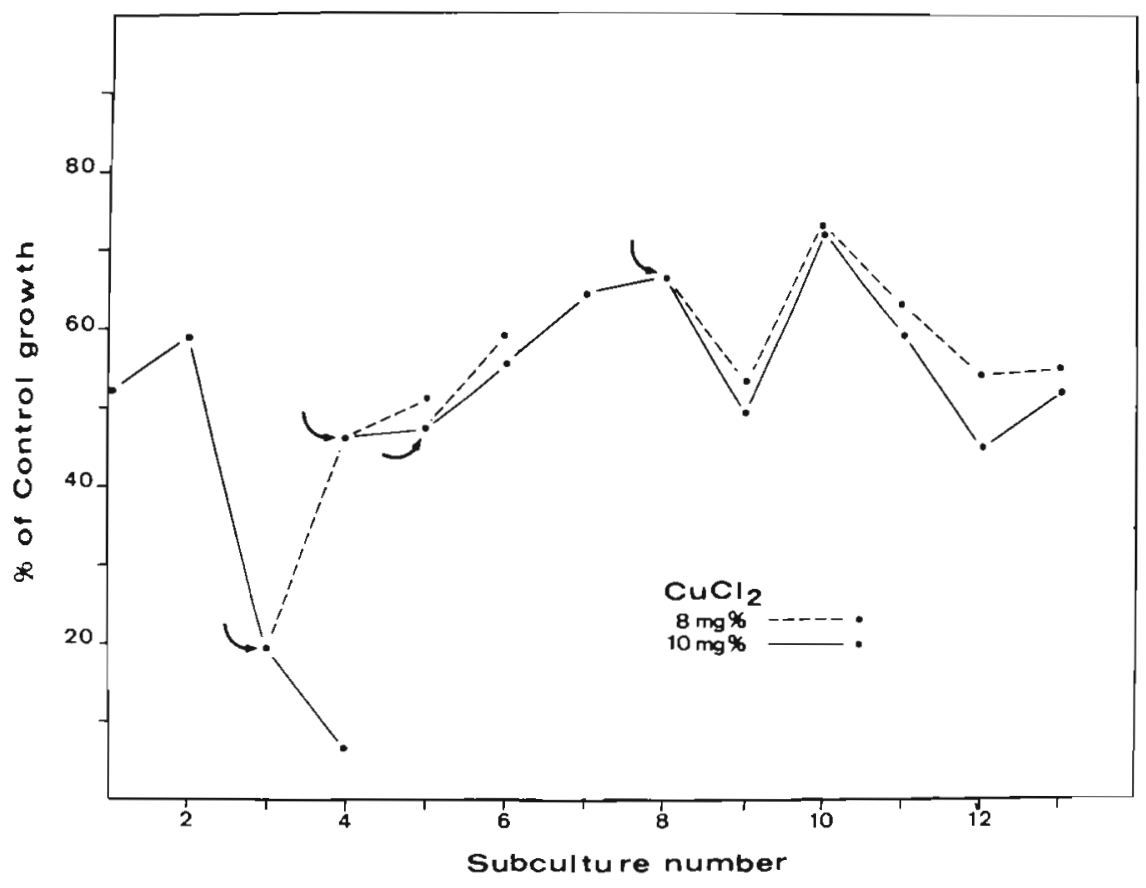

Fig. 8. Isochrysis galbana. Growth during extended exposure to copper by periodic subculture in $\mathrm{ASP}_{2}$ medium containing added $\mathrm{CuCl}_{2} \quad 18 \mathrm{mg} \%$ $\mathrm{CuCl}_{2}=37.8 \mathrm{ppm} \quad \mathrm{Cu}_{i} \quad 10 \mathrm{mg} \%$ $\mathrm{CuCl}_{2}=47.3 \mathrm{ppm} \mathrm{Cu}$ ). Arrows: subcultures at which cells growing in one concentration were continued in this medium and also transferred into an additional higher or lower concentration of $\mathrm{CuCl}_{2}$

$\mathrm{ZnCl}_{2}$ decreased in growth through 4 subcultures. At subculture 3 the viable cell population was transferred into medium with $3.5 \mathrm{mg} \% \mathrm{ZnCl}_{2}$ (16.8 ppm Zn). Cultures slowly increased in density, reaching a maximum of $71 \%$ of the control at Subculture 11 . The appearance of a subsequent reduction in population at Subcultures 12 and 13 may be, in reality, only a reflection of an unusually dense growth in the control cultures rather than an actual decrease in adaptation (Fig, 6).

Growth of Monochrysis lutheri in artificial seawater with $1.5 \mathrm{mg} \% \mathrm{CdCl}_{2}$ was limited to a population of only $5 \%$ of the control in the 2 subcultures, but viable cells were available to be again transferred to media with $1.5 \mathrm{mg} \%$, as well as $2.5 \mathrm{mg} \% \mathrm{CdCl}_{2}(15.3 \mathrm{ppm}$ Cd). The strain in $2.5 \mathrm{mg} \%$ increased to well over $100 \%$ of the control levels between Subcultures 4 and

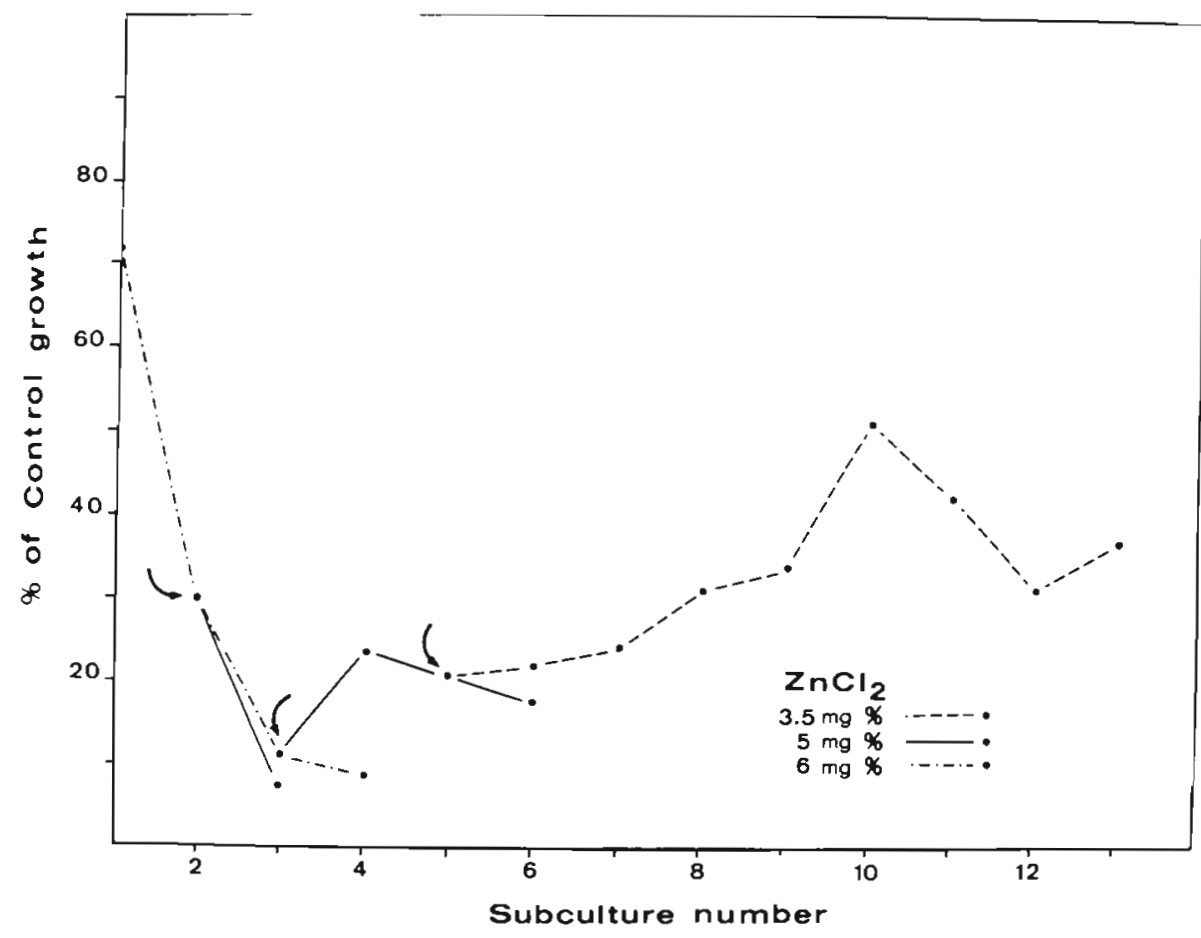

Fig. 9. Isochrysis galbana. Growth during extended exposure to zinc by periodic subculture in medium containing added $\mathrm{ZnCl}_{2}(3.5 \mathrm{mg} \%$ $\mathrm{ZnCl}_{2}=16.8 \mathrm{ppm} \quad \mathrm{Zn} ; \quad 5 \mathrm{mg} \%$ $\mathrm{ZnCl}_{2}=24.0 \mathrm{ppm} \quad \mathrm{Zn} ; \quad 6 \mathrm{mg} \%$ $\mathrm{ZnCl}_{2}=28.8 \mathrm{ppm} \quad \mathrm{Zn}$ ). Arrows: subcultures at which cells growing in one concentration of the metal were continued in this medium and also transferred into an additional higher or lower concentration of $\mathrm{ZnCl}_{2}$ 
Fig. 10. Isochrysis galbana. Growth during extended exposure to cadmium by periodic subculture in medium containing added $\quad \mathrm{CdCl}_{2} \quad(1.5 \mathrm{mg} \%$ $\mathrm{CdCl}_{2}=9.20 \mathrm{ppm} \quad \mathrm{Cd} ; 2.5 \mathrm{mg} \%$ $\mathrm{CdCl}_{2}=15.3 \mathrm{ppm} \quad \mathrm{Cd} ; 5.0 \mathrm{mg} \%$ $\mathrm{CdCl}_{2}=30.7 \mathrm{ppm}$ Cd). Arrows: subcultures at which cells growing in one concentration of the metal were continued in this medium and also transferred into an additional higher or lower concentration of $\mathrm{CdCl}_{2}$

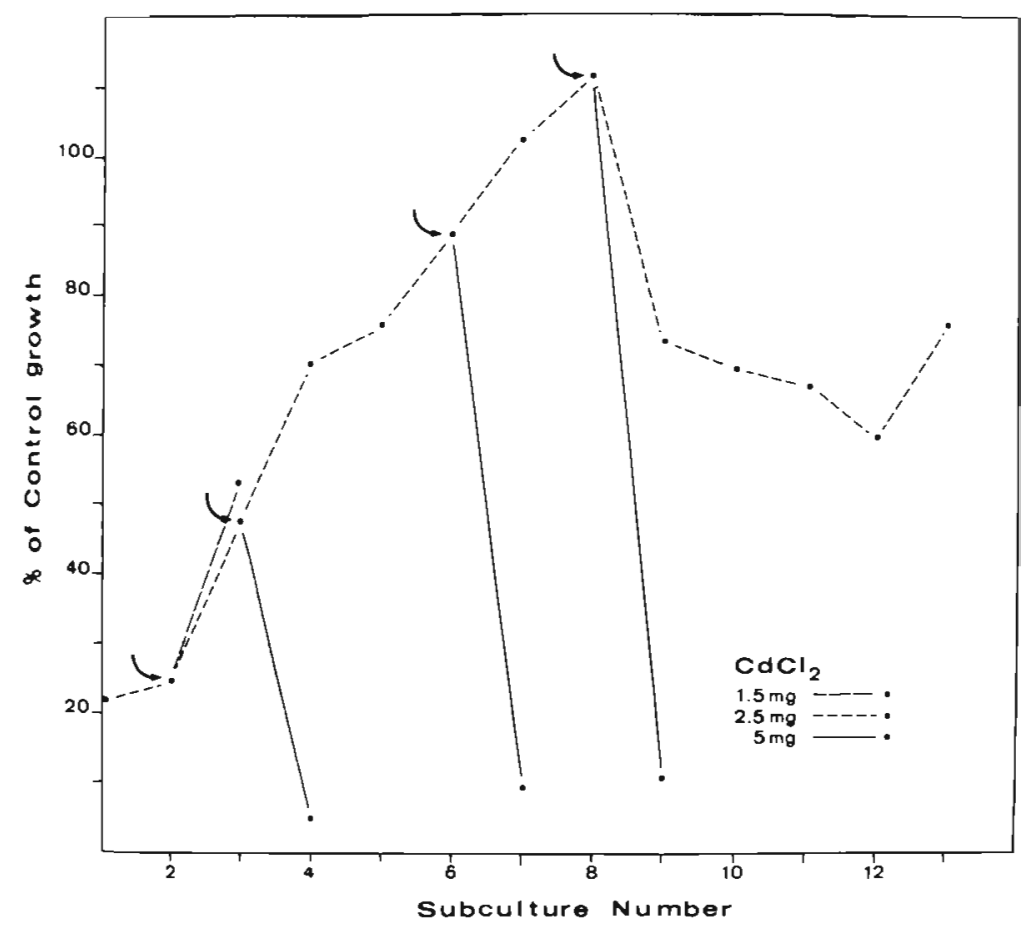

11. However, repeated attempts to grow this species in $5 \mathrm{mg} \% \mathrm{CdCl}_{2}$ medium failed (Fig. 7).

Growth of Isochrysis galbana in medium with $10 \mathrm{mg} \% \mathrm{CuCl}_{2} \quad(47.3 \mathrm{ppm} \mathrm{Cu})$ was greatly reduced after 4 subcultures. Inoculation of $8 \mathrm{mg} \% \quad \mathrm{CuCl}_{2}$ medium with viable cells from the $10 \mathrm{mg} \%$ culture yielded populations that were judged to be sufficient for the next transfer to be again in the higher concentration of $\mathrm{CuCl}_{2}$. Growth in $10 \mathrm{mg} \%$ was now satisfactory, and the strain was continued. Algae from the latter strain were used to re-inoculate $8 \mathrm{mg} \% \mathrm{CuCl}_{2}$ medium to determine if this strain would show an improved growth density in the lower copper concentration. In fact, this did not occur, and both strains in $8 \mathrm{mg} \%$ and $10 \mathrm{mg} \% \mathrm{CuCl}_{2}$ demonstrated a reasonably steady growth that remained between $50 \%$ and $70 \%$ of the control for the duration of the experiment (Fig. 8).

Isochrysis galbana in $5 \mathrm{mg} \%$ and $6 \mathrm{mg} \% \quad \mathrm{ZnCl}_{2}$ media was depressed. At Subculture 5, the declining $5 \mathrm{mg} \% \mathrm{ZnCl}_{2}$ strain was used to inoculate medium containing less $\mathrm{ZnCl}_{2}, 3.5 \mathrm{mg} \%$ (16.8 ppm $\mathrm{Zn}$ ). The latter strain gradually increased to $50 \%$ of the control between Subcultures 6 and 10 (Fig. 9).

Isochrysis galbana inoculated into medium with $2.5 \mathrm{mg} \% \mathrm{CdCl}_{2}(15.3 \mathrm{ppm} \mathrm{Cd})$ resulted in only a little over $20 \%$ of control growth, but subsequently showed a steady increase to over $100 \%$ in 8 subcultures. Repeated attempts to grow this strain in $5 \mathrm{mg} \% \mathrm{CdCl}_{2}$ medium were not successful (Fig. 10).

Dunaliella euchlora proved to be very resistant to copper, growing above $80 \%$ of the control levels in medium with $25 \mathrm{mg} \% \mathrm{CuCl}_{2}$ (118 ppm Cu). Growth was further stimulated to $120 \%$ of the controls after 6 subcultures and subsequently remained between $80 \%$ and $100 \%$ of the controls (Fig. 11). D. euchlora in $6 \mathrm{mg} \% \mathrm{ZnCl}_{2}$ decreased in growth with the first 3 subcultures but, at the 2nd subculture, a strain in $5 \mathrm{mg} \% \mathrm{ZnCl}_{2}$ (24.0 ppm $\mathrm{Zn}$ ) was started and density in this concentration eventually increased. This strain was again put into $6 \mathrm{mg} \% \mathrm{ZnCl}_{2}$ where it then appeared to tolerate temporarily the higher metal concentration. At the 9th subculture the declining strain in $6 \mathrm{mg} \%$ was transferred to medium with $5 \mathrm{mg} \% \mathrm{ZnCl}_{2}$, and growth continued to improve (Fig. 12).

Growth of Dunaliella euchlora in $10 \mathrm{mg} \% \mathrm{CdCl}_{2}$

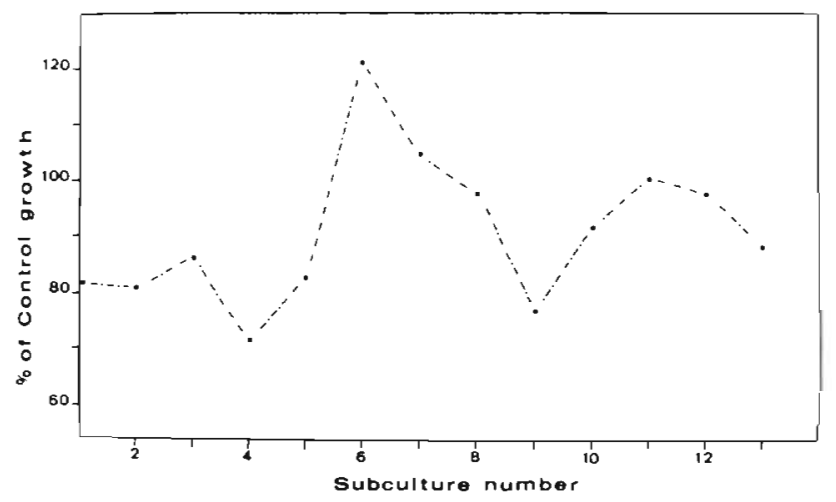

Fig. 11. Dunaliella euchlora. Growth during extended exposure to copper by periodic subculture in $\mathrm{ASP}_{2}$ medium containing added $\mathrm{CuCl}_{2}\left(25 \mathrm{mg} \% \mathrm{CuCl}_{2}=118 \mathrm{ppm} \mathrm{Cu}\right)$ 


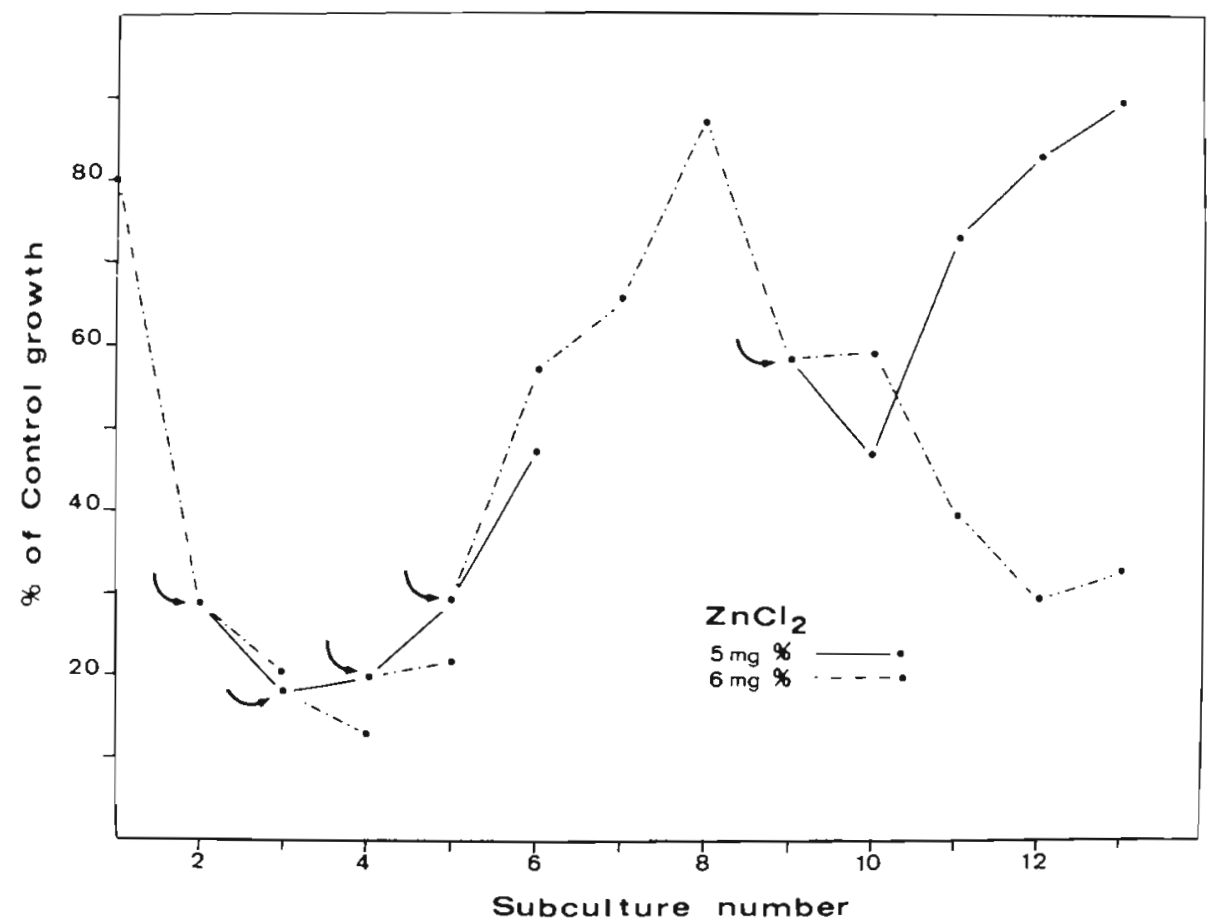

Fig. 12. Dunaliella euchlora Growth during extended exposure to zinc by periodic subculture in $\mathrm{ASP}_{2}$ medium containing added $\quad \mathrm{ZnCl}_{2} \quad(5.0 \mathrm{mg} \%$ $\mathrm{ZnCl}_{2}=24.0 \mathrm{ppm} \quad \mathrm{Zn}$ i $6.0 \mathrm{mg} \%$ $\mathrm{ZnCl}_{2}=28.8 \mathrm{ppm} \mathrm{Zn}$ ). Arrows: subcultures at which cells growing in one concentration of the metal were continued in this medium and also transferred into an additional higher or lower concentration of $\mathrm{ZnCl}_{2}$
(61.3 ppm Cd) medium increased to a maximum of $100 \%$ of the control after 6 subcultures; thereafter, growth varied between $70 \%$ and $95 \%$ of control

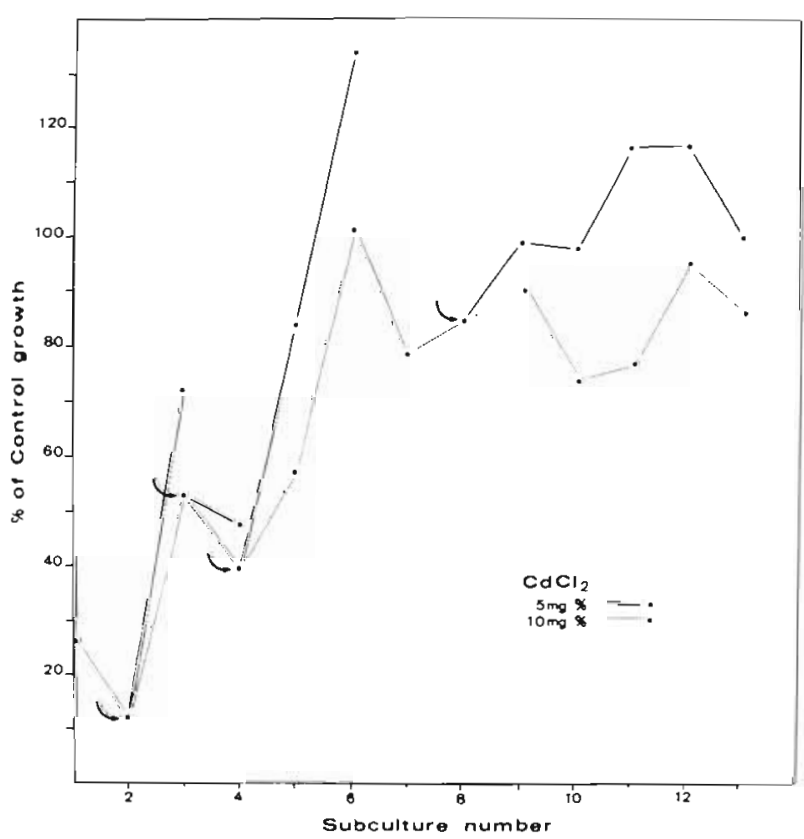

Fig. 13. Dunaliella euchlora. Growth during extended exposure to cadmium by periodic subculture in medium containing added $\mathrm{CdCl}_{2}\left(5 \mathrm{mg} \% \mathrm{CdCl}_{2}=30.7 \mathrm{ppm} \mathrm{Cd} ; 10 \mathrm{mg} \%\right.$ $\mathrm{CdCl}_{2}=61.3 \mathrm{ppm} \mathrm{Cd}$ ). Arrows: subcultures at which cells growing in one concentration of the metal were continued in this medium and also transferred into an additional higher or lower concentration of $\mathrm{CdCl}_{2}$ levels. The $10 \mathrm{mg} \% \mathrm{CdCl}_{2}$ strain was inoculated into $5 \mathrm{mg} \% \mathrm{CdCl}_{2}$ medium, in which growth was stimulated to $133.3 \%$ of the control growth. This procedure was repeated at Subculture 8 and also yielded a culture of high density (Fig. 13).

Medium with $25 \mathrm{mg} \% \mathrm{CuCl}_{2}$ severely reduced growth of Phaeodactylum tricornutum after 3 subcultures. At Subculture 2, cells from the $25 \mathrm{mg} \% \mathrm{CuCl}_{2}$ transferred into $10 \mathrm{mg} \% \mathrm{CuCl}_{2}(47.3 \mathrm{ppm} \mathrm{Cu})$ medium attained $105 \%$ of the control growth at Subculture 5 . Attempts to grow the $10 \mathrm{mg} \% \mathrm{CuCl}_{2}$ strain in $25 \mathrm{mg} \%$ $\mathrm{CuCl}_{2}$ medium were not successful (Fig. 14).

Growth of Phaeodactylum tricornutum failed in $6 \mathrm{mg} \%$ and $5 \mathrm{mg} \% \mathrm{ZnCl}_{2}$. A $3.5 \mathrm{mg} \% \mathrm{ZnCl}_{2}$ (16.8 ppm $\mathrm{Zn})$ strain, after an initial decline, eventually grew to population densities of $60 \%$ of the control, but this stimulation was only temporary, and density declined after the 11th subculture (Fig. 15).

Phaeodactylum tricornutum in $20 \mathrm{mg} \% \mathrm{CdCl}_{2}(123$ ppm Cd) medium grew to just over $60 \%$ of control levels in the 1st subculture. This strain was continued for 13 subcultures, during which growth was erratic, but the strain remained between $60 \%$ and $80 \%$ of control levels. At various times the $20 \mathrm{mg} \% \mathrm{CdCl}_{2}$ strain was used to inoculate $10 \mathrm{mg} \%$ medium, and cells from this culture subsequently were used to inoculate $5 \mathrm{mg} \% \mathrm{CdCl}_{2}$ medium. Resulting strains in the $5 \mathrm{mg} \%$ and $10 \mathrm{mg} \% \mathrm{CdCl}_{2}$ concentrations grew somewhat better than the $20 \mathrm{mg} \% \mathrm{CdCl}_{2}$ strain, but there was no evidence of significant stimulation with time (Fig. 16). 
Fig. 14. Phaeodactylum tricornutum. Growth during extended exposure to copper by periodic subculture in $\mathrm{ASP}_{2}$ medium containing added $\mathrm{CuCl}_{2} \quad 10 \mathrm{mg} \%$ $\mathrm{CuCl}_{2}=47.3 \mathrm{ppm} \quad \mathrm{Cu} ; \quad 25 \mathrm{mg} \%$ $\mathrm{CuCl}_{2}=118 \mathrm{ppm} \mathrm{Cu}$ ). Arrows: subcultures at which cells growing in one concentration of the metal were continued in this medium and also transferred into an additional higher or lower concentration of $\mathrm{CuCl}_{2}$
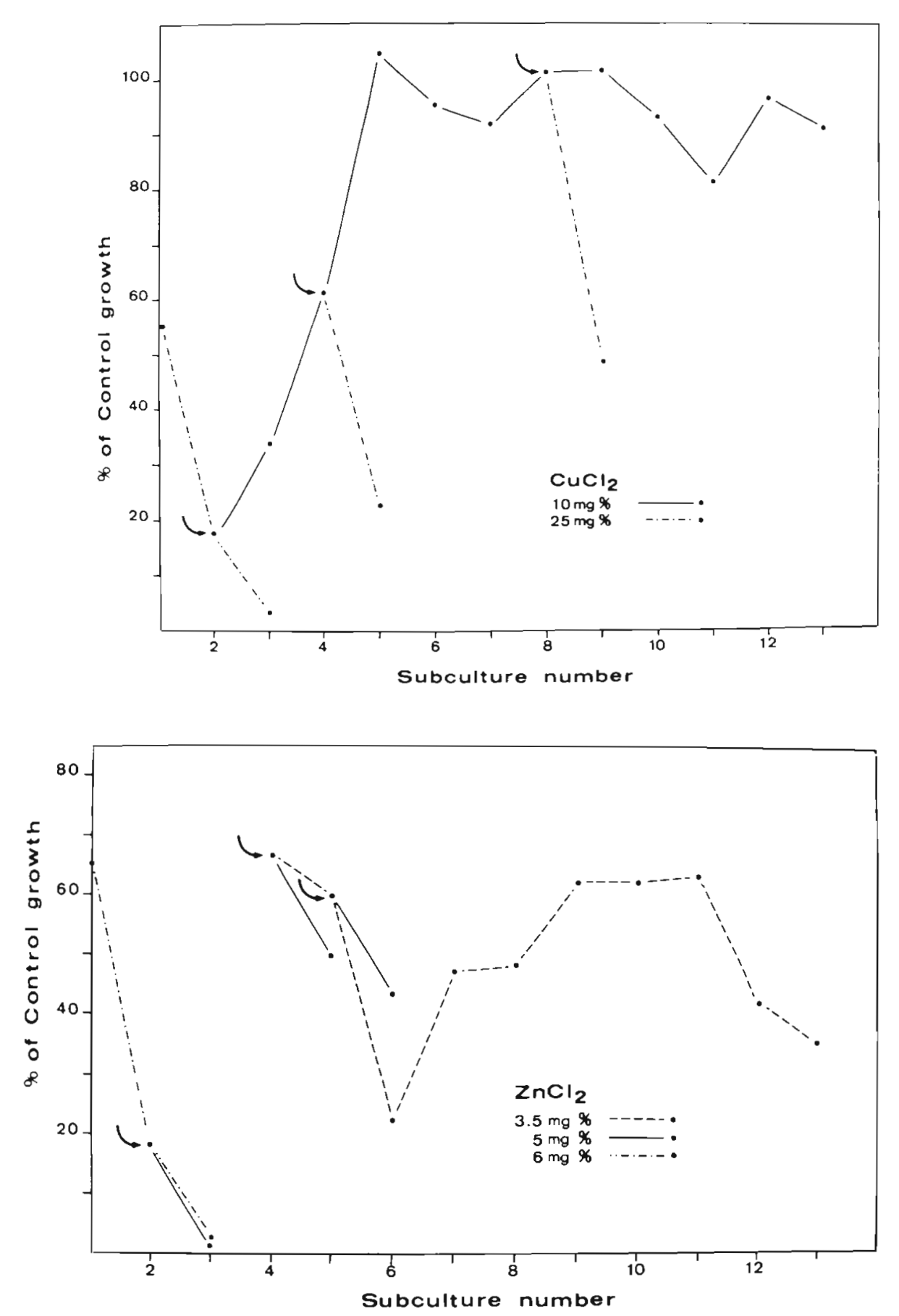

Fig. 15. Phaeodactylum tricornutum. Growth during extended exposure to zinc by periodic subculture in medium containing added $\quad \mathrm{ZnCl}_{2} \quad(3.5 \mathrm{mg} \%$ $\mathrm{ZnCl}_{2}=16.8 \mathrm{ppm} \quad \mathrm{Zn} ; \quad 5.0 \mathrm{mg} \%$ $\mathrm{ZnCl}_{2}=24.0 \mathrm{ppm} \quad \mathrm{Zn} ; \quad 6.0 \mathrm{mg} \%$ $\mathrm{ZnCl}_{2}=28.8 \mathrm{ppm} \mathrm{Zn}$ ). Arrows: subcultures at which cells growing in one concentration of the metal were continued in the medium and also transferred into an additional higher or lower concentration of $\mathrm{ZnCl}_{2}$. At the 4 th subculture the stock strain growing in $\mathrm{ASP}_{2}$ was transferred into $3.5 \mathrm{mg} \% \mathrm{ZnCl}_{2}$

\section{Microscopic Examination of Adapted Strains}

Samples taken from the highest concentration of each metal at Subculture 11 were examined microscopically. No evident morphological anomalies or consistent size differences were observed after extended exposure to the metals.

\section{Feeding of Crassostrea virginica Larvae with Metal-} Adapted Algal Strains

Development at $48 \mathrm{~h}$ of at least $75 \%$ of the fertilized egg suspension to normal veliger larvae was used as criterion of a healthy population required for conducting experiments. Average size of veligers at $48 \mathrm{~h}$ was 


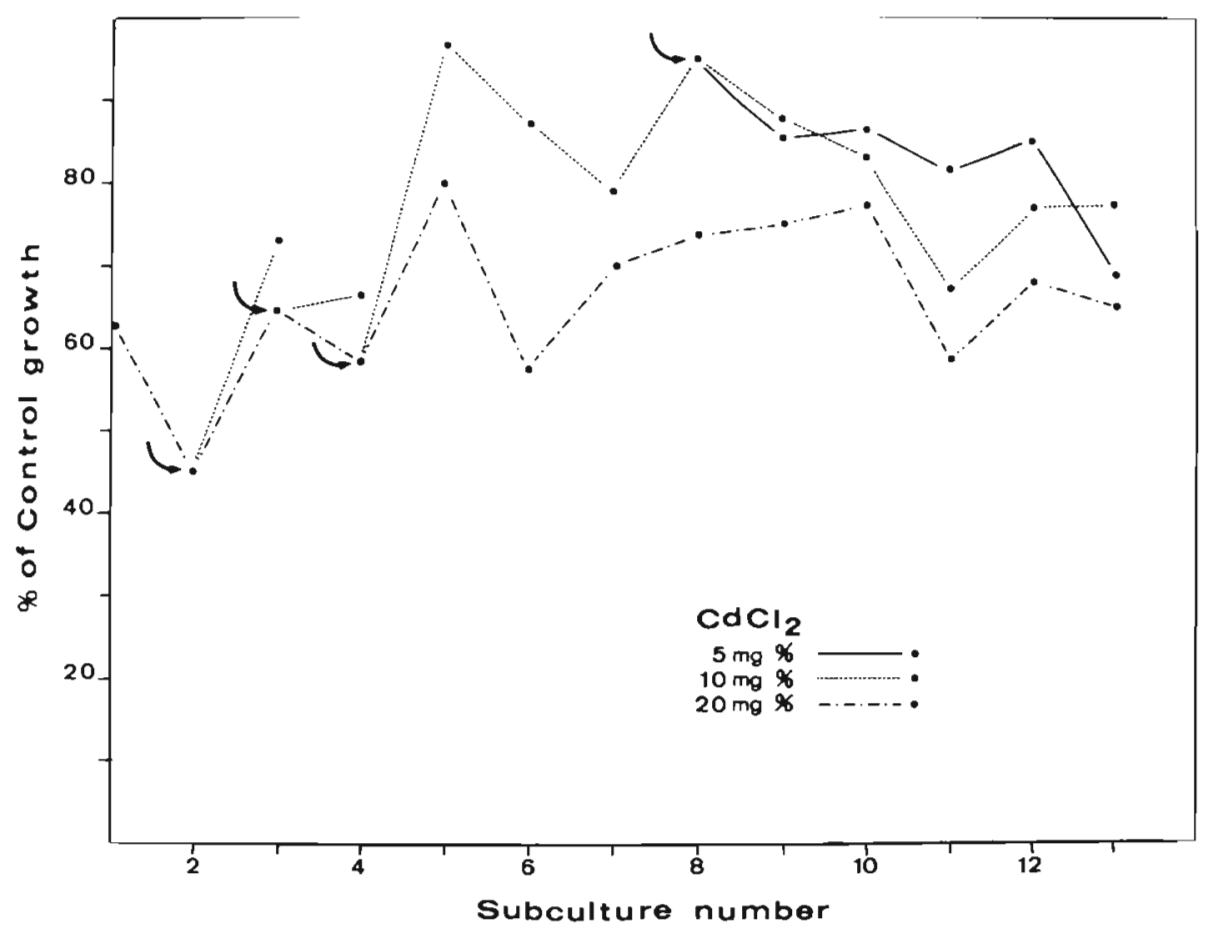

Fig. 16. Phaeodactylum tricornutum. Growth during extended exposure to cadmium by periodic subculture in medium containing added $\quad \mathrm{CdCl}_{2} \quad 15.0 \mathrm{mg} \%$ $\mathrm{CdCl}_{2}=30.7 \mathrm{ppm} \quad \mathrm{Cd} ; \quad 10 \mathrm{mg} \%$ $\mathrm{CdCl}_{2}=61.3 \mathrm{ppm} \quad \mathrm{Cd} ; \quad 20 \mathrm{mg} \%$ $\mathrm{CdCl}_{2}=123 \mathrm{ppm}$ Cd). Arrows: subcultures at which cells growing in one concentration of the metal were continued in this medium and also transferred into an additional higher or lower concentration of $\mathrm{CdCl}_{2}$

$79 \mu \mathrm{m}$. On the 5 th day of the experiment, unfed larvae averaged $80.6 \mu \mathrm{m}$; larvae not fed but treated with $86 \mu \mathrm{g} \mathrm{l}^{-1}$ (ppb) copper ion in solution were $85.6 \mu \mathrm{m}$; and larvae not fed but treated with $27 \mu \mathrm{m} \mathrm{l}^{-1}$ cadmium ion in solution, $84.8 \mu \mathrm{m}$. In contrast, larvae fed daily with living Isochrysis galbana cultured in $\mathrm{ASP}_{2}$ medium were $120.9 \mu \mathrm{m}$ in size. The average sizes of larvae fed $I$. galbana plus copper in solution, and larvae fed $I$. galbana plus cadmium in solution were $128.7 \mu \mathrm{m}$ and $128.8 \mu \mathrm{m}$, respectively. Larvae fed $I$. galbana adapted to $2.5 \mathrm{mg} \% \mathrm{CdCl}_{2} \quad(15.3 \mathrm{ppm} \quad \mathrm{Cd})$ attained $128.9 \mu \mathrm{m}$. However, algae adapted to $10 \mathrm{mg} \%$ $\mathrm{CuCl}_{2}(47.3 \mathrm{ppm} \mathrm{Cu})$, exerted an inhibitory effect upon larval survival and growth. After $5 \mathrm{~d}$ of feeding, these larvae averaged only $89.2 \mu \mathrm{m}$. Larval growth after 2,5 , and $8 \mathrm{~d}$ of feeding is given in Table 4 .

All unfed larvae showed high mortality on Days 2 and 5; unfed larvae treated with metals in solution exhibited only slightly higher mortalities. Mortality of larvae fed living Isochrysis galbana plus metals in solution was not appreciably higher than that of larvae fed living $I$. galbana alone. Feeding of larvae with copper-adapted I. galbana strains resulted in the highest mortality. Mortality of larvae in samples taken on the 2nd, 5th, and 8 th days of feeding is listed in Table 4 .

Larvae were observed under the fluorescence microscope to ascertain that cells from the various Isochrysis

Table 4. Crassostrea virginica. Growth and mortality of larvae in 8 feeding regimes. Food organism: Isochrysis galbana

\begin{tabular}{|c|c|c|c|c|c|c|}
\hline \multirow[t]{2}{*}{ Feeding regime } & \multicolumn{3}{|c|}{$\begin{array}{c}\text { Size of larvae }(\mu \mathrm{m}) \\
\text { Day fed }\end{array}$} & \multicolumn{3}{|c|}{$\begin{array}{c}\text { Percent of larvae dead } \\
\text { Day fed }\end{array}$} \\
\hline & 2 & $5 \cdots$ & 8 & 2 & 5 & 8 \\
\hline Unfed larvae & 85.9 & $80.4 \pm 0.39$ & • & 6.8 & 26.7 & $\cdot$ \\
\hline Unfed larvae $\perp \mathrm{Cu}\left(86 \mu \mathrm{g} \mathrm{I}^{-1}\right)$ & 82.8 & $86.0 \pm 0.47$ & $\cdot$ & 11.7 & 48.1 & $\cdot$ \\
\hline Unfed larvae $+\mathrm{Cd}\left(27 \mu \mathrm{g} \mathrm{l}^{-1}\right)$ & 84.1 & $84.8 \pm 0.48$ & $\cdot$ & 19.5 & 35.2 & • \\
\hline Larvae fed $I$ galbana $\cdots$ & 100.0 & $120.5 \pm 0.84$ & 160.0 & 2.6 & 8.0 & 14.4 \\
\hline Larvae fed $I$ galbana $+\mathrm{Cu}^{++}\left(86 \mu \mathrm{g} \mathrm{l}^{-1}\right)$ & 100.0 & $128.7 \pm 0.78$ & 148.5 & 2.5 & 8.6 & 10.9 \\
\hline Larvae fed $I$ galbana $+\mathrm{Cd}^{++}\left(27 \mu \mathrm{gl}^{-1}\right)$ & 98.9 & $128.8 \pm 0.65$ & 150.0 & 3.4 & 8.4 & 9.8 \\
\hline Larvae fed $I$ galbana adapted to $10 \mathrm{mg} \% \mathrm{CuCl}_{2}$ & 83.1 & $89.0 \pm 0.60$ & 104.5 & 36.2 & 44.4 & 61.3 \\
\hline Larvae fed I. galbana adapted to $2.5 \mathrm{mg} \% \mathrm{CdCl}_{2}$ & 88.1 & $128.9 \pm 0.76$ & 153.0 & 18.7 & 25.7 & 30.6 \\
\hline \multirow{2}{*}{\multicolumn{7}{|c|}{$\begin{array}{l}\text { - Samples not measured or counted; all larvae dead } \\
\text {. Probable error calculated for Day } 5\end{array}$}} \\
\hline & & & & & & \\
\hline \multicolumn{7}{|c|}{$\cdots$ Number of cells fed $=16.5 \times 10^{3}$ cells $\mathrm{ml}^{-1}$ of larval culture (containing 20 larvae ml ${ }^{-1}$} \\
\hline
\end{tabular}


galbana strains were indeed being ingested. Autofluorescence of algae within fed larvae revealed that the larvae were ingesting and lysing $I$. galbana cells, including those adapted to copper and cadmium (Fig. 17). Particulate and partially lysed I. galbana were observed in all feeding regimes.

\section{DISCUSSION}

Mineral elements, both major and trace, are essential nutrients for micro-algae (O'Kelley, 1974) but, in excessive concentration or the wrong speciation, can become toxic (Allen et al., 1980). Copper toxicity for micro-algae has been known since early in the century when copper sulphate was used to control nuisance growths of algae in eutrophic lakes (Moor and Kellerman, 1904). Later, oxides of metals were incorporated into boat and gear paints to discourage attachment of algae and other planktonic forms (Orton, 1929-30). Recently, attention is being paid to the role of metals as inhibitors of primary productivity in aquatic environments, both freshwater (Steemann-Nielsen and WiumAndersen, 1969, 1970; Whitton, 1970) and marine (Davies, 1978; Thomas et al, 1980).

In the present study, extensive growth inhibition of Monochrysis lutheri and Isochrysis galbana became evident in $47.3 \mathrm{ppm} \mathrm{Cu}$ in the enriched natural seawater medium, but inhibition occurred at more than twice this concentration, $118 \mathrm{ppm} \mathrm{Cu}$, in the artificial seawater medium. Dunaliella euchlora and Phaeodactylum tricornutum showed similar responses (about $80 \%$ of control growth) at $47.3 \mathrm{ppm} \mathrm{Cu}$ in natural seawater medium. In the $\mathrm{ASP}_{2}$ medium, however, $D$. euchlora was resistant to $118 \mathrm{ppm} \mathrm{Cu}$; whereas, growth of the diatom was diminished at this concentration. This difference in response of the latter 2 species in the chelated medium suggests that $P$. tricornutum has a far more sensitive metal uptake mechanism than does the flagellate. Davies (1976) demonstrated that the membrane of $D$. tertiolecta was markedly less permeable to mercury than that of $I$. galbana. The latter took up almost 4 times the metal across a unit area of surface in the period of the experiment than did $D$. tertiolecta. The remarkable resistance of $D$. euchlora to copper suggests that a similar difference in the rate of copper uptake exists as that described for mercury by Davies.

Cadmium appeared to be a more potent inhibitor of algal growth than copper. In both media lower concentrations of cadmium inhibited growth of the most sensitive species, Monochrysis lutheri and Isochrysis galbana, than was the case with copper. Cadmium was also a more effective inhibitor than copper of Phaeodactylum tricornutum and Dunaliella euchlora in both media. However, it may be noteworthy that, in

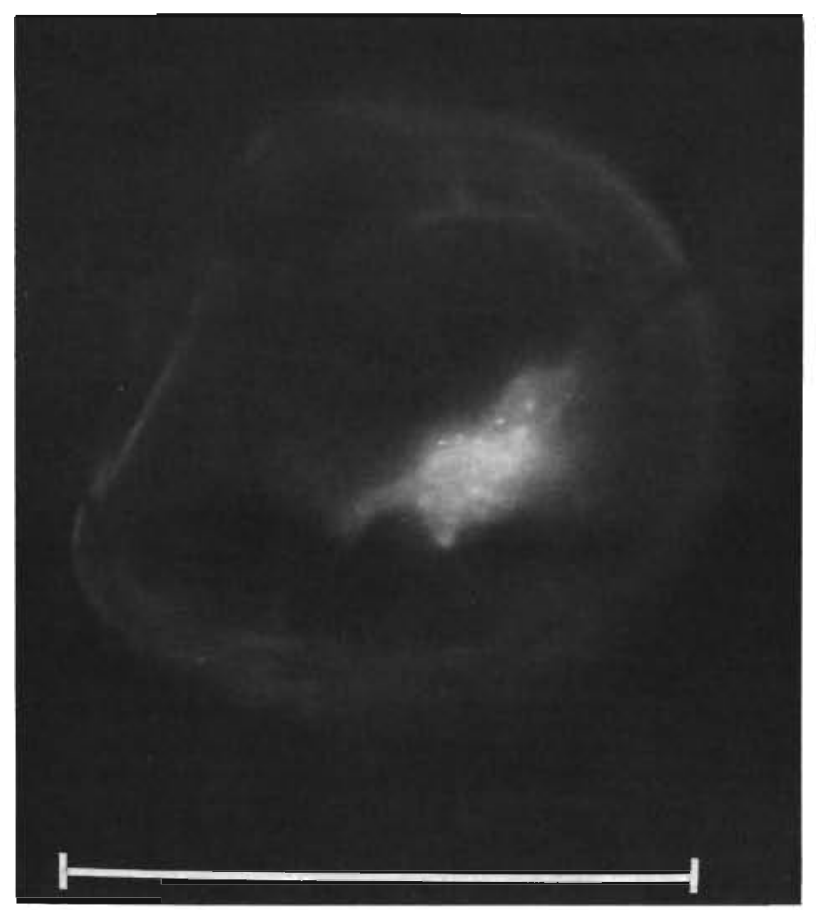

Fig. 17 Crassostrea virginica. Straight-hinge-stage larva fed Isochrysis galbana, adapted to $10 \mathrm{mg} \% \mathrm{CuCl}_{2}(47.3 \mathrm{ppm} \mathrm{Cu})$ for $8 \mathrm{~d}$, showing epifluorescence of whole and partially lysed algal cells in the gut. Sample taken $1 \mathrm{~h}$ after feeding. Scale line: $100 \mu \mathrm{m}$

both media, cadmium inhibited growth of $D$. euchlora more than $P$. tricornutum, which is a reverse of the species response to copper.

Significant growth inhibition occurred in lower concentrations of copper and cadmium in the enriched natural seawater than in the artificial seawater medium. The enriched natural seawater medium (E) contains $\mathrm{NaFe}$ Sequestrene, an iron-specific chelator, and the buffer, tris(hydroxymethyl)aminomethane, which has some complexing properties. On the other hand, the artificial seawater medium $\mathrm{ASP}_{2}$ contains the same concentration of the buffer and, in addition, the strong cationic chelator, disodium ethylenediaminetetracetic acid. The results presented here confirm earlier studies showing that chelation can reduce the toxicity of copper to phytoplankters (Erickson et al., 1970; Steemann-Nielsen and Wium-Andersen, 1970) and that toxicity is related only to the concentration of free cupric ion (Sunda and Guillard, 1976; Anderson and Morel, 1978).

Differences in species sensitivity to metals, such as those observed with copper and cadmium, were not repeated in experiments on tolerance to zinc. In the artificial seawater medium with $33.6 \mathrm{ppm} \mathrm{Zn,} \mathrm{growth}$ of all species ranged from $50.9 \%$ to $64.7 \%$ of controls. In the natural seawater medium, inhibition in 
$48.0 \mathrm{ppm} \mathrm{Zn}$ also remained within a similar range $(25.7 \%-38.4 \%)$ for all species. The work of Davies (1973) supports the hypothesis that $\mathrm{Zn}$ uptake in Phaeodactylum tricornutum is passive. His experiments showed that growing cultures reached a maximum of intracellular zinc in $12-14 \mathrm{~h}$ after the metal was introduced and then decreased steadily, although zinc was still available for additional uptake. If such a phenomenon exists in other phytoplankton as well, a limited capacity to build up intracellular concentrations of zinc could explain the relatively low toxicity of this metal and the similarity of the growth response in different species.

The transfer of metals from the aquatic environment to phytoplankton must take place by either or both of 2 mechanisms: (1) penetration of ions through cell membrane barriers by an active or passive diffusion process; (2) adsorption on the cell surface. A negatively charged surface on 3 species of estuarine micro-algae has been demonstrated experimentally (Myers et al., 1975). These negatively charged adhesive sites, normally coupled to seawater cations, may become displaced by high concentrations of cationic pollutants. In such an event, the relatively large surface area of micro-algae available for sorption, together with the high cell concentrations used in laboratory culture experiments or to be found in natural blooms, presents ample opportunity for the transfer of high concentrations of metallic ions to the grazing species of the next trophic level.

Although studies on adaptation of algae to heavy metals in laboratory or natural environments are scarce, there is evidence that such adaptation exists in the natural environment. Populations of the brown alga Ectocarpus siliculosus isolated from the hulls of freight liners coated with a copper-based anti-fouling paint were reported more resistant to dissolved copper than populations of this alga isolated from an open, uncontaminated rocky shore (Russell and Morris, 1970). A copper-tolerant population of E. siliculosus was shown by Hall (1980) to be co-tolerant to cobalt and zinc in laboratory culture.

Stockner and Antia (1976) criticized much of the literature on phytoplankton pollution stress and bioassay procedures for ignoring the possibility of biological adaptation in these studies. Bioassay studies that measure population growth after exposure of algae to the pollutant for a few days or inhibition of photosynthesis after a brief exposure to the pollutant are not sufficient According to Stockner and Antia . . . it is only the long term response that is expected to be ecologically realistic for application to environmental protection against pollution and eutrophication. 'In addition, they say that rather than concern over the mechanistic nature of this adaptation, i.e. is it acquired via muta- tions or physiologically? . it would be more important to know whether such adaptation may impair the food value of phytoplankton to the next trophic level in the aquatic food web. The present report supports these statements of Stockner and Antia.

All species gave evidence of some capacity for adaptation to metal concentrations that were inhibitory upon initial exposure. There were 3 culture procedures that induced this adaptation: (1) prolonged subculture in a constant sublethal metal concentration, (2) subculture of viable cells from a population diminished by a high metal concentration into a slightly less toxic concentration, and (3) subculture of viable cells to a slightly increased concentration. Each of these procedures or their combinations gave evidence of the potential for adaptation to metals in the tested algae. Although with some cultures no consistent increase in population density was observed with the above procedures, a long-term tolerance or a temporary increase in populations rather than declining growth with time was demonstrated, constituting a type of adaptation.

Tolerance to high metal concentrations could be mediated by developing metabolic pathways as alternatives to those utilizing enzymes sensitive to metallic poisoning or by reducing cell permeability. An alternative adaptation mechanism may be a stimulation of the production of extracellular metabolites that can act as chelators, thereby reducing the effective metal ion concentration. Such extracellular metabolites with chelating potential can be released into the medium, retained intracellularly on non-metabolic binding sites or remain attached to the cell wall (Jackson and Morgan, 1978; Härdstedt-Roméo and Gnassia-Barelli, 1980).

The general binding capacity of compounds, such as protein, provides a method for the storage of metals. Specific storage proteins of the metallothionen type have been discovered in several marine groups, and their synthesis can be induced in the field and laboratory (Bryan, 1979). Whereas the ability of phytoplankters to adapt to metal pollutants is of survival value, this accumulation of metals as storage products possesses a direct threat to the grazing population. Romeril (1971) considered 3 possible methods for accumulation of metals by marine animals: (1) adsorption of ions at membrane/water interfaces; (2) absorption by active and/or passive diffusion of metal ions from seawater across semi-permeable membranes into cell or body fluids; (3) ingestion of ions with food, in combination with particulate matter or mucus, and absorption through the gut wall. Romeril concluded that accumulation by the last of these processes would be small, but an opposite conclusion was reached by Pentreath (1973) from a study conducted on the adult bivalve Mytilus edulis. Metal accumulation by way of food was 
also shown to be important in marine gastropods (Young, 1977; Klumpp, 1980) and the fish Pleuronectes platessa and Raja clavata (Pentreath, 1977). Thus, there is some evidence that planktonic algae, the main primary producers in the marine environment, could be a major entry point of heavy metal ions into the marine food web. This hypothesis is also supported by the data of the present study

Oyster larvae fed cultures of Isochrysis galbana adapted to $10 \mathrm{mg} \% \mathrm{CuCl}_{2}(47.3 \mathrm{ppm} \mathrm{Cu})$ responded with a decreased growth rate, as well as a high mortality. Feeding larvae with copper in solution and algae cultured in the absence of excess metal resulted in growth that was similar to that of the controls and a mortality that was well within the normal expected mortality range. Larvae that were fed I. galbana adapted to $2.5 \mathrm{mg} \% \mathrm{CdCl}_{2}$ (15.3 ppm Cd) or cadmium in solution with normal $I$. galbana were less affected than with copper. Perhaps variation in response to the 2 metals can be attributed to the fact that the algae had been adapted to a lower concentration of cadmium than of copper, thus introducing different amounts of the metals to the larvae. Although growth of larvae was slightly affected by cadmium in solution and by cadmium-adapted algal food, the mortality of larvae fed cadmium-adapted algae was about twice that of larvae fed I. galbana not exposed to high levels of metals. This observation implies that larval populations are not uniform in grazing capacity; individuals that grazed very actively had the opportunity to accumulate higher concentrations of metals than normal grazers. Variation among larvae in grazing ability has often been observed in oyster rearing experiments (Landers and Ukeles, unpubl.).

Our experiments clearly demonstrate how pollutants can affect organisms at higher trophic levels by bioaccumulation from primary producers, while toxic concentrations cause mortality of grazers, accumulation of sublethal concentrations can be passed on and concentrated in species still higher up in the trophic pyramid.

The great disparity of phytoplankton response to metals in laboratory experiments suggests that introduction of metal contaminants into a natural assemblage of estuarine micro-algae can shift the species composition of the assemblage. In fact, it has been shown that introduction of copper to an experimental ecosystem with a natural mixed composition of phytoplankton led to the bloom of one copper-resistant diatom species, Amphiprora paludosa (Sanders et al., 1981).

Bioassay studies must be evaluated in relationship to a particular ecosystem before extrapolating laboratory studies on acute toxicity levels to field conditions. To establish water-quality standards, the potential for complexing of metallic ions should be determined, as well as the possibility of altering species composition and its immediate and chronic impact on the food web.

\section{LITERATURE CITED}

Allen, H. E., Hall, R. H., Brisbin, T D. (1980). Metal speciation. Effects on aquatic toxicity. Environ. Sci. Techn. 14: $441-443$

Amiel, A. J., Navrot, J. (1978). Near shore sediment pollution in Israel by trace metals derived from sewage effluent. Mar. Pollut. Bull. 9: 10-14

Anderson, D. M., Morel, F. M. (1978). Copper sensitivity of Gonyaulax tamarensis. Limnol. Oceanogr 23: 283-295

Babinchak, J., Ukeles, R. (1979). Epifluorescence microscopy, a technique for the study of feeding in Crassostrea virginica veliger larvae. Mar. Biol. 51: 69-76

Boyden, C.R. (1975). Distribution of some trace metals in Poole Harbour, Dorset. Mar Pollut. Bull. 6: 180-187

Braek, G. S., Malnes, D., Jensen, A. (1980). Heavy metal tolerance of marine phytoplankton. IV. Combined effects of zinc and cadmium on growth and uptake in some marine diatoms. J. exp. mar Biol. Ecol. 42: 39-54

Bryan, G.W (1971). The effects of heavy metals (other than mercury) on marine and estuarine organisms. Proc. R. Soc. (Ser. B.) $177: 389-410$

Bryan, G.W (1979). Bioaccumulation of marine pollutants. In: Cole, H. A. (ed.) The assessment of sublethal effects of pollutants in the sea. Phil. Trans. Soc. (Ser B.) 286: 483-505

Calabrese, A., Macinnes, J.R., Nelson, D. A., Miller, J. E (1977). Survival and growth of bivalve larvae under heavy-metal stress. Mar Biol. 41 179-184

Cole, H. A. (ed) (1979). The assessment of sublethal effects of pollutants in the sea. Proc. Discussion Meeting, R. Soc., 24-25 May 1978

Coombs, T L. (1972). The distribution of zinc in the oyster Ostrea edulis and its relation to enzymic activity and to other metals. Mar Biol. 12: 170-178

Coombs, T L. (1974). The nature of zinc and copper complexes in the oyster Ostrea edulis. Mar. Biol. 28: 1-10

Cossa, D. (1976). Sorption du cadmium par une population de la diatomée Phaeodactylum tricornutum en culture. Mar. Biol. 34: 163-167

Cossa, D., Poulet, S. A. (1978). Survey of trace metal contents of suspended matter in the St. Lawrence Estuary and Saguenay Fjord. J. Fish. Res. Bd Can. 35: 338-345

Davies, A. G. (1973). The kinetics of and a preliminary model for the uptake of radio-zinc by Phaeodactylum tricornutum in culture. In: Radioactive contamination of the marine environment. Proc. Symposium, Seattle, 1972, International Atomic Energy Agency, Vienna, pp. 403-420

Davies, A. G. (1976). An assessment of the basis of mercury tolerance in Dunaliella tertiolecta. J. mar biol. Ass. U. K. 56: $39-57$

Davies, A. G. (1978). Pollution studies with marine plankton Part II Metals. Adv. mar Biol. 15: 38-508

Davis, H.C., Guillard, R. R. (1958). Relative value of ten genera of micro-organisms as foods for oyster and clam larvae. Fish. Bull. Fish Wildl. Serv. U. S. 58 (136) : 293-304

Erickson, S. J., Lackie, N., Maloney, T. E. (1970). A screening technique for estimating copper toxicity to estuarine phytoplankton. J. Wat. Pollut. Control Fed. 42: R270-278

Establier, R., Pasqual, E. (1974). Estudios del cobre, hierro, manganeso, y cincen en ostiones (Crassostrea angulata) del golfo de Cadiz. Inv. Pesq. 38: 371-384 
Feng, S. Y., Ruddy, G. M. (1974). Zn, Cu, Cd, Mn, and $\mathrm{Hg}$ in oysters along the Connecticut coast. In: Dehlinger, P. W., et al. (eds.) Sea grant report, Investigations on concentrations, distributions, and fates of heavy metal wastes in parts of Long Island Sound. University of Connecticut Marine Sciences Institute, Groton, Conn. 06340

Friberg, L., Piscator, M., Nordberg, G. F., Kjellström, T (1974). Cadmium in the environment, C. R. C. Press Inc., Boca Raton, Florida

Greig, R., Reid, R. N., Wenzloff, D. R. (1977). Trace metal concentrations in sediments from Long Island Sound. Mar. Pollut. Bull. 8: 188-192

Hall, A. (1980). Heavy metal co-tolerance in a copper-tolerant population of the marine fouling alga Ectocarpus siliculosus (Dillw.) Lyngbye. New Phytol. 85: 73-78

Hall, R. A., Zook, E. G., Meaburn, G. M. (1976). National Marine Fisheries Service survey of trace elements in the fishery resources. NOAA, NMFS, Southeast Fisheries Center, College Park, Md 20740

Härdstedt-Roméo, M., Gnassia-Barelli, M. (1980). Effect of complexation by natural phytoplankton exudates on the accumulation of cadmium and copper by Haptophyceae. Mar Biol. 59: 79-84

Ikuta, K. (1968). Studies on accumulation of heary metals in aquatic organisms. II. On accumulation of copper and zinc in oysters. Bull. Japan. Soc. scient. Fish. 34: 112-116

Jackson, G. A., Morgan, J. J. (1978). Trace metal-chelator interactions and phytoplankton growth in seawater media. Theoretical analysis and comparison with reported observations. Limnol. Oceanogr. 13: 268-282

Kidder, G. M. (1977). Pollutant levels in bivalves: a data bibliography. The Mussel Watch Program (EPA contract) Scripps Institution of Oceanography, La Jolla, Calif.

Klumpp, D. W (1980). Accumulation of arsenic from water and food by Littorina littoralis and Nucella lapillus. Mar. Biol. 58: 265-274

Korringa, P. (1971). Marine pollution and its biological consequences. In: Costlow, J. D. (ed.) Fertility of the sea. Gordon and Breach Science Publishers, New York

Loosanoff, V. L., Davis, H. C. (1963). Rearing of bivalve mollusks. Adv. mar. Biol. 1: 1-136

McLachlin, J. (1960). The culture of Dunaliella tertiolecta (Butcher) a euryhaline organism. Can. J. Microbiol. 6: 367-379

Moor, G. T., Kellermann, K. F. (1904). A method of destroying or preventing growth of algae in certain pathogenic bacteria in water supplies. Bur. Plant Industries, U. S. Dept. Agriculture Bull. 64

Myers, V. B., Iverson, R. L., Harris, R. C. (1975). The effect of salinity and dissolved organic matter on surface charge characteristics of some euryhaline phytoplankton. J. exp. mar. Biol. Ecol. 17: 59-68

Nielsen, S. A. (1975). Cadmium in New Zealand dredge oysters: geographic distribution. Internatl. J. environ. analyt. Chem. 4: 1-7

O'Kelley, J.C. (1974). Inorganic nutrients. In: Stewart, D. W. F. (ed.) Algal physiology and biochemistry (Botanical Monographs Vol. 10), University of California Press, Berkeley and Los Angeles, pp. 610-635

Orton, J. H. (1929-30). Experiments in the sea on the growthinhibitive preservative value of poisonous paints and other substances. J. mar biol. Ass. U. K. 16: 373-452

Pentreath, R. J. (1973). The accumulation from water of ${ }^{64} \mathrm{Zn}$ ${ }^{54} \mathrm{Mn},{ }^{58} \mathrm{Co},{ }^{59} \mathrm{Fe}$ by the mussel Mytilus edulis. J. mar. biol. Ass. U. K. 53: 127-143
Pentreath, R. J. (1977). The accumulation of cadmium by the plaice Pleuronectes platessa and the thornback ray Raja clavata L. J. exp. mar. Biol. Ecol. 30: 223-232

Pringle, B. H., Hissong, D. E., Katz, E. L., Mulawka, S. T (1968). Trace metal accumulation by estuarine molluscs. J sanit. Engng Div. Am. Soc. civ. Engrs 94: 455-475

Provasoli, L., McLaughlin, J. J. A., Droop, M. R. (1957). The development of artificial media for marine algae. Arch Mikrobiol. 25: 392-428

Romeril, M. G. (1971). The uptake and distribution of ${ }^{65} \mathrm{Zn}$ in oysters. Mar. Biol. 9: 347-354

Russell, G., Morris, O.P. (1970). Copper tolerance in the marine fouling alga Ectocarpus siliculosus. Nature, Lond 228: 288-289

Sanders, J. G., Batchelder, J. H., Ryther, J. H. (1981). Dominance of a stressed marine phytoplankton assemblage by a copper-tolerant pennate diatom. Botanica Mar. 24 $39-41$

Steemann-Nielsen, E., Wium-Andersen, S. (1969). The effect of deleterious concentrations of copper on the photosynthesis of Chlorella pyrenoidosa. Physiol. Plant. 22: $1121-1133$

Steemann-Nielsen, E., Wium-Andersen, S. (1970). Copper ions as poison in the sea and fresh water Mar. Biol. 6: 93-97

Stockner, J. G., Antia, N. J. (1976). Phytoplankton adaptation to environmental stresses from toxicants, nutrients, and pollutants - a warning. J. Fish. Res. Bd Can. 33: 2089-2096

Sunda, W., Guillard, R. R. L. (1976). The relationship between cupric ion activity and the toxicity of copper to phytoplankton. J. mar. Res. 34: 511-529

The New York Times (1978). Health specialists concerned over cadmium peril. June 15: A13

The New York Times (1980). Study finds toxic waste polluting L. I. drinking water. July 9: B5

Thomas, W. H., Hollibaugh, J. T., Seibert, D. L. R., Wallace, G. T., Jr. (1980). Toxicity of a mixture of ten metals to phytoplankton. Mar. Ecol. Prog. Ser. 2: 213-220

Ukeles, R. (1971). Nutritional requirements in shellfish culture. In: Price, K. S., Jr, Maurer, D. L. (eds.) Proc. conf. artificial propagation of commercially valuable shellfish. College of Marine Studies, Univ. Delaware, Newark, Delaware

Ukeles, R. (1973). Continuous culture - a method for the production of unicellular algal foods. In: Stein, J. R. (ed.) Handbook of phycological methods. Cambridge University Press, Cambridge, pp. 233-254

Valiela, 1., Banus, M. D., TeaI, J. M. (1974). Response of salt marsh bivalves to enrichment with metal-containing sewage sludge and retention of lead, zinc, and cadmium by marsh sediments. Environ. Pollut. 7: 149-157

Walne, P. R. (1963). Observations on the food value of seven species of algae to larvae of Ostrea edulis. I. Feeding experiments. J mar. biol. Ass. U. K. 43: 767-784

Whitton, B. A. (1970). The toxicity of heavy metals to fresh water algae: A review. Phycos 9: 116-125

Windom, H. L., Smith, R. G. (1972). Distribution of cadmium, cobalt, nickel, and zinc in southeastern United States continental shelf waters. Deep Sea Res. 19:727-730

Wolfe, D. A. (1970). Zinc enzymes in Crassostrea virginica. J. Fish. Res. Bd Can. 27: 59-69

Young, M. L. (1977). The role of food and direct uptake from water in the accumulation of zinc and iron in the tissues of the dogwhelk Nucella lapillus (L.). J. exp. Mar. Biol. Ecol. 30: $315-325$ 